\title{
Method Development And Validation Of Valacyclovir In Bulk \& Tablet Dosage Form By Rphplc Method
}

\author{
Sheetal Ramya Lahari.N.A. \\ (Department of pharmaceutical Analysis, Balaji Instiute of Pharmaceutical Sciences/Kakatiya \\ University, INDIA)
}

\begin{abstract}
A reverse phase high performance liquid chromatography (RP-HPLC) has been developed for the estimation of valacyclovir in bulk drug and pharmaceutical dosage form. The method is carried out using C8 agilent zorbax column $150 \mathrm{~cm} \times 4.6 \mathrm{~mm} \times 5$ micron and mobile phase consisting of phosphate buffer at pH 3.0: water: methanol $(50: 50 \% \mathrm{v} / \mathrm{v})$, at flow rate of $1 \mathrm{~mL} / \mathrm{min}$. The column temperature is $25^{\circ} \mathrm{C}$. Eluents were monitored by UV detector set at $253 \mathrm{~nm}$. The method was statistically validated in terms of linearity, accuracy, precision, systemsuitability and robustness in accordance with ICH guidelines.Linear regression analysis data for the calibration plot showed that there was a linear relationship between response and concentration in the range of $20-150 \mathrm{mcg} / \mathrm{ml}$ and the correlation coefficient is 0.9999 . The retention time found to be $2.02 \mathrm{~min}$. Literature survey reveals analytical methods for the estimation of Valacyclovir from pharmaceutical dosage forms and also in biological fluids. The proposed method was found to be simple, precise, accurate, rapid and reproducible for the estimation of valacyclovir in bulk drug and tablet.
\end{abstract}

Key words:Valacyclovir, RP-HPLC Method,Validation,Linearity.

\section{INTRODUCTION}

Valacyclovir hydrochloride is $L$-valine, 2-[(2-amino-1,6-dihydro-6-oxo-9H-purin-9-yl)methoxy]ethyl ester, monohydrochloride.It is an antiviral agent which is used in the treatment of herpes zoster and herpes simplex virus. Literature survey reveals few analytical methods for the estimation of valacyclovir from pharmaceutical dosage forms and also in biological fluids. Due to the increasing importance of speed and reliability of analysis in pharmaceutical analytical laboratories, a new method for determination of valacyclovir in formulations with a short time of analysis $(5 \mathrm{~min}$ ) with retention time 2.027 minutes is described in this work. It is fast and quick chromatographic method in terms of retention time and run time when compared with other reported methods described in literature survey.

\subsection{DRUG PROFILE:}

Name

\section{: VALACYCLOVIR}

Structure

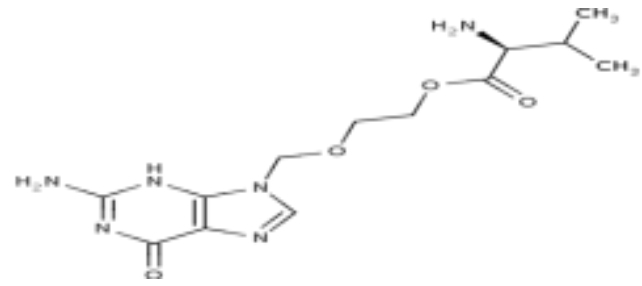

ChemicalName methylbutanoate.

Molecular Formula Molecular Weight

Nature

Solubility

Pka

Therapeutic Category

$\lambda_{\max }$
(S)-2-[(2-amino-6-oxo-6,9-dihydro-3H-purin-9yl)methoxy]ethyl- 2-amino-3- -

$$
\begin{array}{ll}
: & \mathrm{C}_{13} \mathrm{H}_{20} \mathrm{~N}_{6} \mathrm{O}_{4} \\
: & 360.80 \\
: & \text { White -Offwhite capsule shaped film coated tablets } \\
: & \text { soluble in water } \\
: & 1.90,7.47 \text {, and } 9.43 . \\
: & \text { Anti-viral Agent. } \\
: & 253 \mathrm{~nm} .
\end{array}
$$


Half life

Bioavailability

Excretion

Metabolism

Storage
$<30 \mathrm{~min}$ valacyclovir.2.5-3.6hrs acyclovir $\sim 55 \%$ (oral)

renal(40-50\%)acyclovir, and fecal (47\%)

Hepatic $(50-70 \%)$ to acyclovir

stored under cool and dry place.

\subsection{Chemicals/ Reagents and Solvents:}

Table.3. Chemicals and Reagents

\begin{tabular}{|c|c|c|c|}
\hline S. No. & $\begin{array}{c}\text { Chemicals/standards and } \\
\text { reagents }\end{array}$ & Grade & Make \\
\hline 1 & $\begin{array}{c}\text { Potassium dihydrogen } \\
\text { phosphate }\end{array}$ & AR & $\begin{array}{c}\text { Thomas } \\
\text { Baker }\end{array}$ \\
\hline 2 & Ortho phosphoric acid & AR & Merck \\
\hline 3 & HPLC Grade Methanol & HPLC & Merck \\
\hline 4 & HPLC Grade Acetonitrile & HPLC & Merck \\
\hline 5 & Double Distilled Water & HPLC & Loba Chemi \\
\hline 6 & Valacyclovir & N/A & $\begin{array}{c}\text { MSN } \\
\text { Laboratories }\end{array}$ \\
\hline
\end{tabular}

\subsection{Instruments and Equipments:}

Table.4.Instruments and Equipments

\begin{tabular}{|c|c|c|c|c|}
\hline S.NO. & $\begin{array}{c}\text { Instruments } \\
\text { And } \\
\text { Equipments }\end{array}$ & Software & Model & Company \\
\hline 1 & HPLC & Empower 2 & $\begin{array}{c}\text { Alliance 2695, } \\
\text { Detector 2487 }\end{array}$ & WATERS \\
\hline 2 & $\begin{array}{c}\text { Spectrophotom } \\
\text { eter }\end{array}$ & UV Win & $\begin{array}{c}\text { Spectrophoto } \\
\text { meterT60 } \\
\text { (model) }\end{array}$ & $\begin{array}{c}\text { Analytical } \\
\text { technologies } \\
\text { Limited }\end{array}$ \\
\hline 3 & $\begin{array}{c}\text { Weighing } \\
\text { Balance }\end{array}$ & N/A & ER200A & ASCOSET \\
\hline 4 & Sonicator & N/A & SE60US & ENERTECH \\
\hline 5 & pH Meter & N/A & AD102U & ADWA \\
\hline
\end{tabular}

Marketed Formulation: Valcivir- 500mg

\section{METHODOLOGY}

In the present investigation, a simple and sensitive HPLC method was developed for quantitative estimation of valacyclovirin bulk drug and pharmaceutical formulations. A Rapid, Precise, Accurate, Specific and Simple HPLC method was developed for determination of valacyclovir in pharmaceutical formulation using PDA detector. The presented method was simple, since diluted samples are directly used without an preliminary chemical derivatisation or purification steps.

\subsection{Method Development and Optimization Of Chromatographic Parameters:}

\subsubsection{Selection of wavelength:}

The sensitivity of the HPLC method which uses UV detection depends upon the proper selection of wavelength. An ideal wavelength is one that gives good response for all the drugs to be detected. A UV spectrum of Valacyclovir was recorded between 200-400nm (Fig.8). 


\subsubsection{Selection of chromatographic methods:}

The proper selection of methods depends upon the nature of the sample (ionic or ionisable or neutral molecule) its molecular weight and stability. The drugs selected are polar, ionic and Reversed phase chromatography can be used because of its simplicity and suitability.

\subsubsection{Development of RP-HPLC method for Valacyclovir:}

The objective of this experiment was to optimize the assay method for estimation of Valacyclovir based on the literature survey made. So here the trials mentioned describes how the optimization was done. The Chromatograms were showed in Fig:7,8 and .

TRIAL: 1

- $\quad$ Buffer preparation: Transferred $7 \mathrm{ml}$ of Triethylamine into $1000 \mathrm{ml}$ of water and the $\mathrm{PH}$ was adjusted to 3 with Orthophosphoric acid, filtered through $0.45 \mu \mathrm{m}$ nylon membrane filter and degassed.

- Mobile phase: Buffer and Methanol were mixed in the ratio of 70:30 and sonicated to degas.

- Chromatographic conditions:

Flow rate

$1.0 \mathrm{ml} / \mathrm{min}$

Column

Detector wavelength

Column temperature

Thermo $\mathrm{C}_{8}$ column, $(4.6 * 150 \mathrm{~mm}, 3.5 \mu \mathrm{m})$

Injection volume

$253 \mathrm{~nm}$

Run time

Ambient

$10 \mu 1$

$10 \mathrm{~min}$

- Observation: Peak shape is not good and Asymmetry is more than limit.

TRIAL: 2

- $\quad$ Buffer preparation: Transferred $2 \mathrm{ml}$ of orthophosphoric acid into $1000 \mathrm{ml}$ of water and the PH was adjusted to 2.5 with triethylamine, filtered through $0.45 \mu \mathrm{m}$ nylon membrane filter and degassed.

- Mobile phase: Buffer and Methanol were mixed in the ratio of 60:40 and sonicated to degas.

- Chromatographic conditions:

Flow rate

$1.2 \mathrm{ml} / \mathrm{min}$

Column $\quad: \quad$ Thermo $\mathrm{C}_{8}$ column, $(4.6 * 150 \mathrm{~mm}, 3.5 \mu \mathrm{m})$

Detector wave length $\quad: \quad 253 \mathrm{~nm}$

Column temperature : $\quad 30^{\circ} \mathrm{c}$

Injection volume $\quad: \quad 10 \mu 1$

Run time $\quad: \quad 10$ mins

- Observation: Theoretical plates are less .

TRIAL: 3

- Buffer preparation: Transferred $5 \mathrm{ml}$ of Triethylamine into $1000 \mathrm{ml}$ of water and the PH was adjusted to 3 with Orthophosphoric acid, filtered through $0.45 \mu \mathrm{m}$ nylon membrane filter and degassed.

- Mobile phase: Buffer and Methanol were mixed in the ratio of 50:50 and sonicated to degas.

- Chromatographic conditions:

Flow rate $\quad: 1.2 \mathrm{ml} / \mathrm{min}$

Column : Agilent zorbax RP C-8column with 150 x $4.6 \mathrm{~mm}, 5 \mu \mathrm{m}$

Detector wavelength : $253 \mathrm{~nm}$

Column temperature : Ambient

Injection volume $\quad: 20 \mu 1$

Run time : $10 \mathrm{~min}$

- $\quad$ Observation: The retention time is more, peak tailing is observed.

After several trials with the different combination and ratio of solvents, the mobile phase composition of $0.1 \mathrm{M}$ Phosphate Buffer: Methanol $(50: 50)$ of $\mathrm{pH} 3.0 \pm 0.05$ was used and the chromatogram was recorded with flow rate of $1.0 \mathrm{ml} / \mathrm{min}$ with UV detection at $253 \mathrm{~nm}$ and was showed in Fig: 14. The retention time of valacyclovir was $2.02 \mathrm{~min}$ and the run time was less than $6 \mathrm{~min}$. Linearity was observed over concentration range of $20-150$ $\mu \mathrm{g} / \mathrm{ml}$.

\subsubsection{Optimized Method: Fig.9:}

- Buffer preparation: Transferred $5 \mathrm{ml}$ of Triethylamine into $1000 \mathrm{ml}$ of water and the PH was adjusted to 3 with Orthophosphoric acid, filtered through $0.45 \mu \mathrm{m}$ nylon membrane filter and degassed.

- Mobile phase: Buffer and Methanol were mixed in the ratio of 50:50 and sonicated to degas.

- Chromatographic conditions: 
Column

Column temperature

Flow rate

Injection volume

Wavelength

Run time

Diluent

Mobile Phase

The proposed method was validated for various parameters like Linearity, Accuracy, Precision, Robustness, and System Suitability according to ICH guidelines. Commercial tablet formulations and laboratory prepared dilutions were successfully analyzed using the developed methods.

\subsection{Experimental Details:}

\subsubsection{Apparatus and Soft ware:}

The liquid chromatographic system consisted of following components: Waters 2695 HPLC model (automated) containing variable wavelength programmable PDA (Photo diode array) detector . Chromatographic analysis was performed using Empower2 software on a Agilent zorbax RP C-8column with 150 x $4.6 \mathrm{~mm}$ i.d. and $5 \mu \mathrm{m}$ particle size.

\subsubsection{Collection of solvents:} experiment.

HPLC grade Methanol, Phosphate Buffer, Ortho Phosphoric acid, was used as solvents through out the

\subsubsection{Reagents and Pharmaceutical Preparations:}

Valacyclovir was kindly supplied by MSNlaboratories (Hyderabad, A.P and India). All the solvents used in HPLC method are of HPLC grade. Commercial pharmaceutical preparations of Valacyclovir(Valcivir) from local market. Which were claimed to contain $500 \mathrm{mg}$ Valacyclovir was used in analysis.

\subsubsection{Buffer:}

A solution of $13.80 \mathrm{gm}$ of potassium bi phosphate was dissolved in $900 \mathrm{ml}$ of Hplc grade water, mix well by using sonicator, and make up the volume to $1000 \mathrm{ml}$ with water. The $\mathrm{pH}$ of the resulting solution was adjusted to $3.0 \pm 0.5$ with $10 \%$ ortho phosphoric acid. The above solution was filtered through a $0.45 \mu \mathrm{m}$ pore size nylon filter and degassed by ultra sonicator.

\subsubsection{Preparation of standard Valacyclovir solution:}

Accurately weighed $10 \mathrm{mg}$ of pure drug was taken in clean, dry $100 \mathrm{ml}$ volumetric flask and dissolved in small volume of mobile phase and made up the volume to $100 \mathrm{ml}$ with mobile phase. This gave $100 \mathrm{mcg} / \mathrm{ml}$ of drug concentration.From this $0.5 \mathrm{ml}$ make up to $10 \mathrm{ml}$ with mobile phase. $(\mathrm{conc}=50 \mathrm{mcg} / \mathrm{ml})$.

\subsubsection{Pharmaceutical Preparations:.}

Total of 10 tablets were accurately weighed and powdered in a mortar. An amount equivalent to $10 \mathrm{mg}$ of valcyclovir was taken and dissolved in $50 \mathrm{ml}$ of mobile phase and sonicate for $5 \mathrm{~min}$. About $50 \mathrm{ml}$ of mobile phase was added and sonicate for further 5 minutes. The mixture was shaking well for 2 minutes and transferred to a100 ml volumetric flask through a Whatman Filter paper No. 41. The residue was washed thrice with mobile phase and the combined filtrate was made up to the mark with mobile phase. This gave $100 \mathrm{mcg} / \mathrm{ml} \mathrm{of} \mathrm{drug}$ concentration.

Chromatographic conditions:

Mobile phase

Flow rate

Column

Detector wave length

Column temperature

Injection volume

Run time

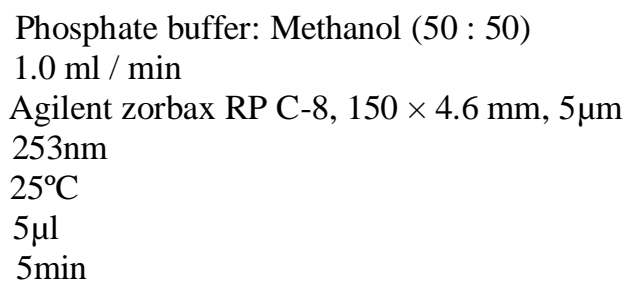

\subsection{Assay Procedure:}

Inject $20 \mu \mathrm{L}$ of the standard and sample solutions into the HPLC system and the chromatograms were recorded Fig.16, 17. Measured the areas for the Linezolid peaks and calculate the \%Assay by using following formulae: 
$\%$ Assay $=\frac{A t}{A s} \times \frac{W s}{D s} \times \frac{D t}{W t} \times \frac{P}{100} \times \frac{\text { avg weight }}{\text { label claim }} \times 100$

Where,

At $=$ average area counts of sample preparation.

As $=$ average area counts of standard preparation.

Ws $=$ Weight of working standard taken in $\mathrm{mg}$.

$\mathrm{Wt}=$ Weight of sample taken in $\mathrm{mg}$.

$\mathrm{Dt}=$ sample dilution

Ds $=$ standard dilution

$\mathrm{P}=$ Percentage purity of working standard

Amount found $(\mathrm{mg})=\frac{\% \text { of Drug }}{100} \times$ label claim

\subsection{Validation of Analytical Method:}

Validation of a method is the process to establish by laboratory studies that the performance characteristic of the method meets the requirements for the intended analytical application. Performance characteristics were expressed in terms of analytical Parameters.

\subsubsection{Accuracy:}

Accuracy of the method was determined by recovery experiments. Recover y studies were carried out by adding known amount of standard drug solution to the sample solution. The $\%$ recovery was calculated and reported in Table:5.

\subsubsection{Precision:}

The Precision of the analytical method was studied by analysis of multiple sampling of homogeneous sample. The Precision expressed as standard deviation or relative standard deviation. The experiment was repeated three times in a day and the average \% RSD values of the results were calculated. When the experiment was repeated on three different days the average \% RSD values for determination of Valacyclovir were calculated.

(a). System precision: System-suitability tests are an integral part of method development and are used to ensure adequate performance of the chromatographic system. Retention time (Rt), number of theoretical plates $(\mathrm{N})$ and tailing factor $(\mathrm{T})$ were evaluated for six replicate injections of the drug at a concentration of $100 \mu \mathrm{g} / \mathrm{ml}$. The results were within acceptable limits and given in Table: 6

(b)Method precision: The precision of the method was demonstrated by intra-day and inter-day precision studies. Intra-day studies were performed by injecting six (6) repeated injections of $100 \%$ concentration from tablet solution within a day. Peak area and \%RSD were calculated and reported in Table-7. Inter-day precision studies, was done by injecting six (6) repeated injections of $100 \%$ concentration from tablet solution for six consecutive days. Peak area and \%RSD were calculated and reported in Table-7.

\subsubsection{Linearity:}

The linearity of the method was demonstrated over the concentration range of $20-150 \mu \mathrm{g} / \mathrm{ml}$ of the target concentration. Aliquots of 20,50,100,120 and $150 \mu \mathrm{g} / \mathrm{ml}$ were prepared from stock solution. The chromatograms was recorded in Fig27-31..A Calibration curve was produced by analyzing different concentrations of the pure drug from the chromatogram in Fig. 32 .

The correlation coefficient for the peak area at each level versus concentration of analyte was calculated and reported in Table 9. and the calibration parameters of Valacyclovir were showed in Table 9.

\section{Acceptance criteria:}

1. Correlation Coefficient should be not less than 0.9990 .

\section{Observation:}

1. The correlation coefficient was found to be 0.999 .

2. From the above study it was established that the linearity of test method is from $20 \%$ to $150 \%$ of the target concentration. 


\subsubsection{Robustness:}

The Robustness of an analytical method was determined by analysis of aliquots from homogenous lots by differing physical parameters that may differ but are still within the specified parameters of the assay. Analyze the sample separately by deliberate changes in the analytical method as given below:

(a) Effect of variation of flow rate:

A study was conducted to determine the effect of variation in flow rate. Standard solution was prepared as per the testing method and was injected into the HPLC system by keeping flow rates, $1.0 \mathrm{ml} / \mathrm{min}, 0.8 \mathrm{ml} /$ $\mathrm{min}$ and $1.2 \mathrm{ml} / \mathrm{min}$. Evaluate the system suitability parameters for $1.0 \mathrm{ml} / \mathrm{min}, 0.8 \mathrm{ml} / \mathrm{min}$ and $1.2 \mathrm{ml} / \mathrm{min}$ flow. The chromatograms were recorded and were presented in Fig: 33 and 34.

\section{Acceptance criteria:}

1. The Tailing Factor of Valacyclovir standards should be $\leq 2.0$ for Variation in flow.

\section{(b) Effect of variation in Temperature:}

A study was conducted to determine the effect of variation in temperature.Standard solution was prepared as per the testing procedure. By Changing the temperature i.e. $30^{\circ} \mathrm{c}$ injected into the column and the chromatograms were recorded, presented as Fig: 35 and 36.

\section{Acceptance criteria:}

1. The Tailing Factor of Valacyclovir standard should be $\leq 2.0$ for Variation in mobile phase concentration.

\section{FIGURES AND TABLES:}

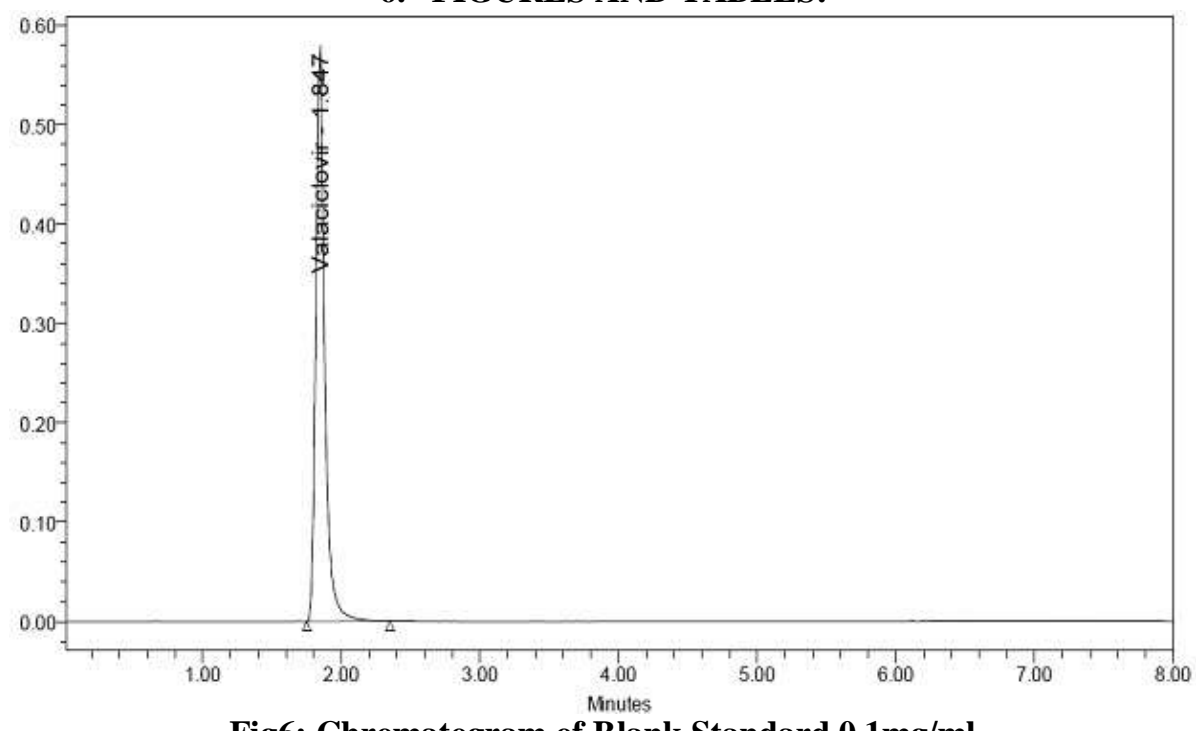

Fig6: Chromatogram of Blank Standard 0.1mg/ml

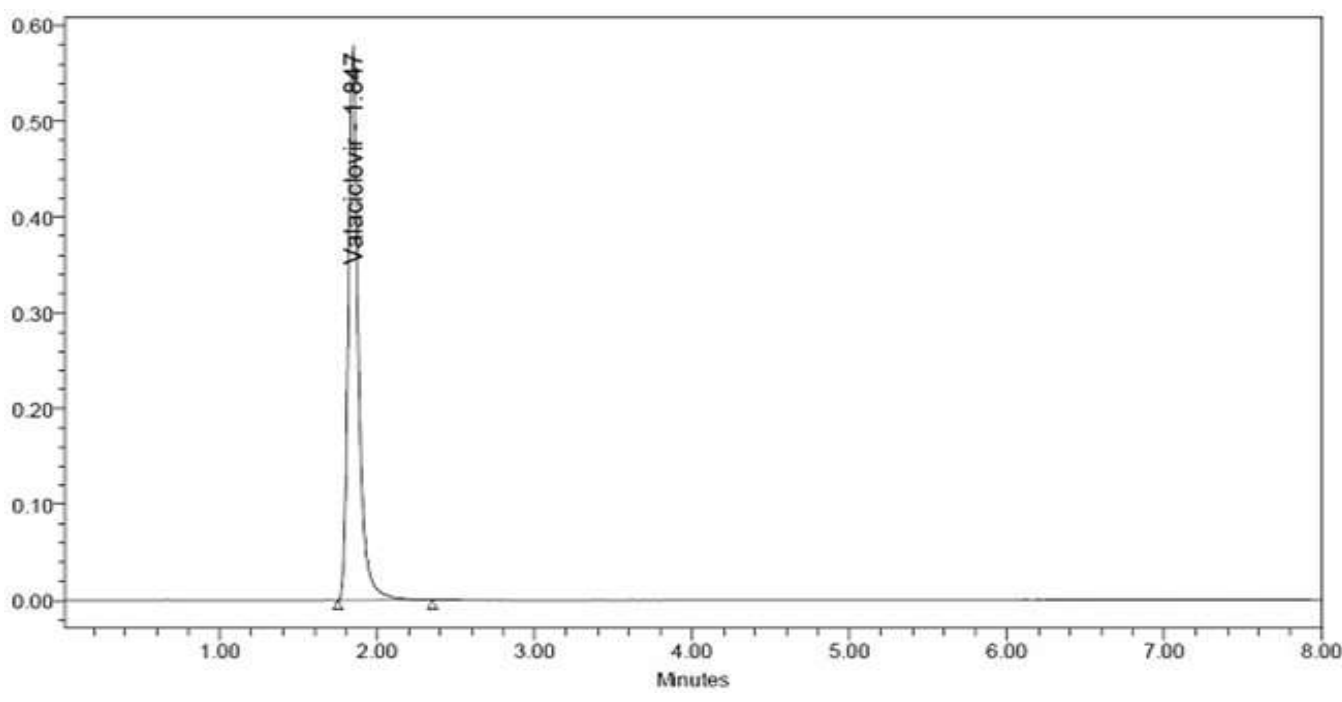




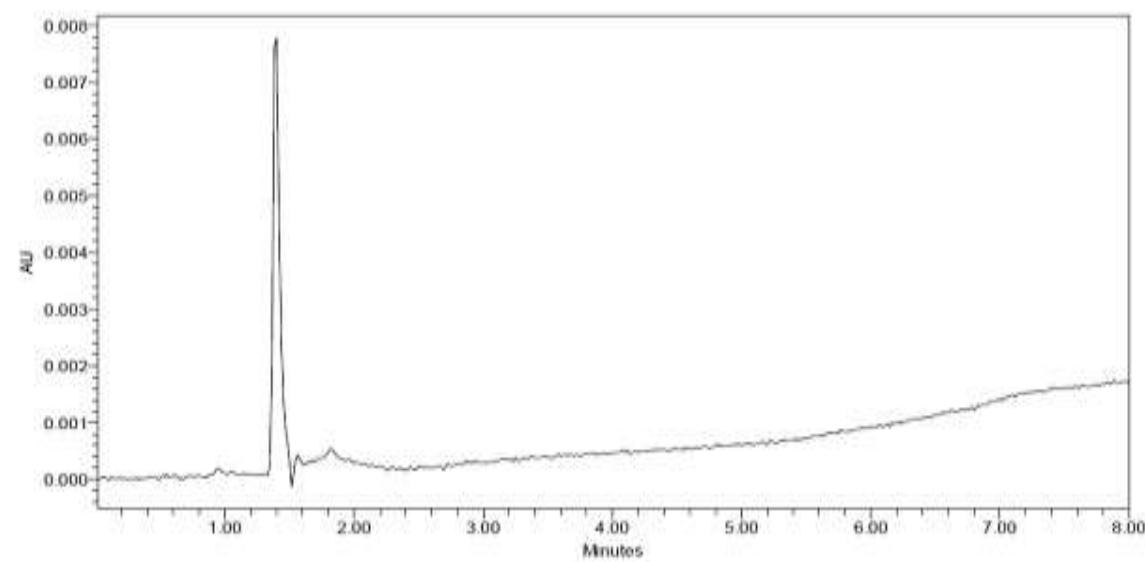

Fig7: Chromatogram Of Standard Mobile Phase 60:40: Water: Methanol

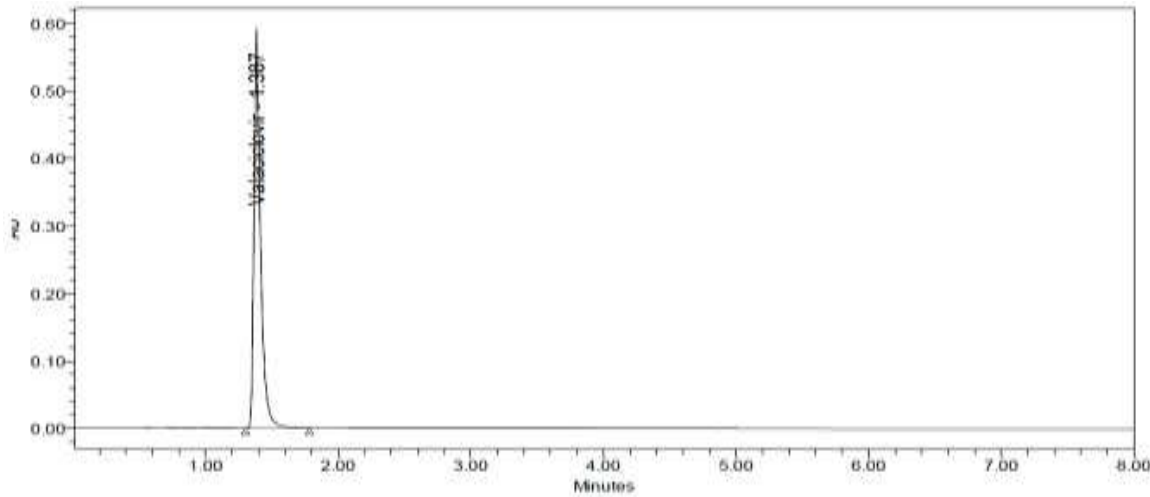

Fig: 8. Chromatogram for Standard Mobile phase pH 3.2 Trial-2

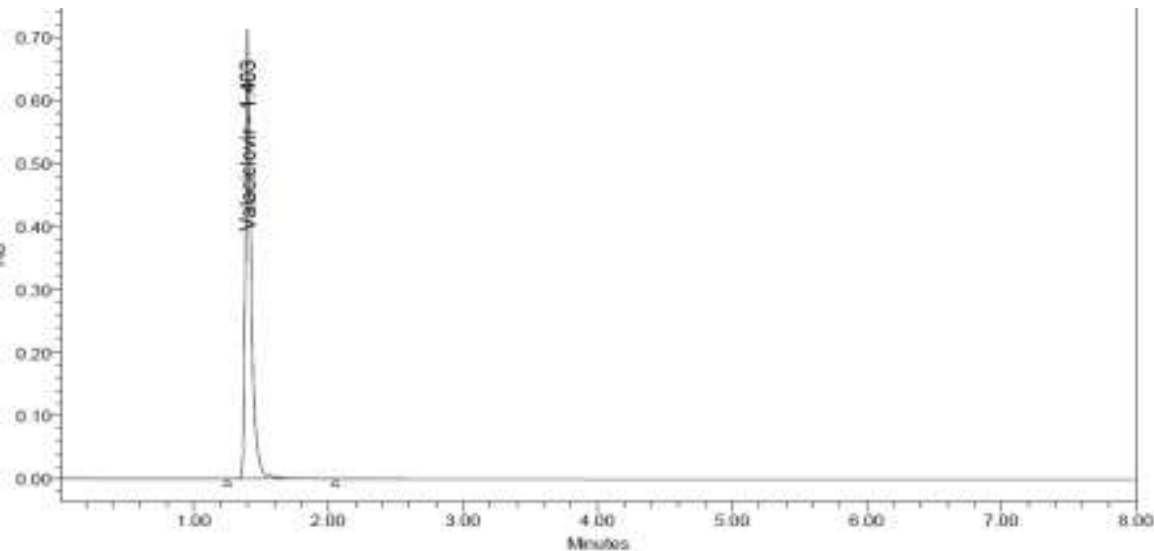

Fig:9. Chromatogram for standard 30 degree Trial-3

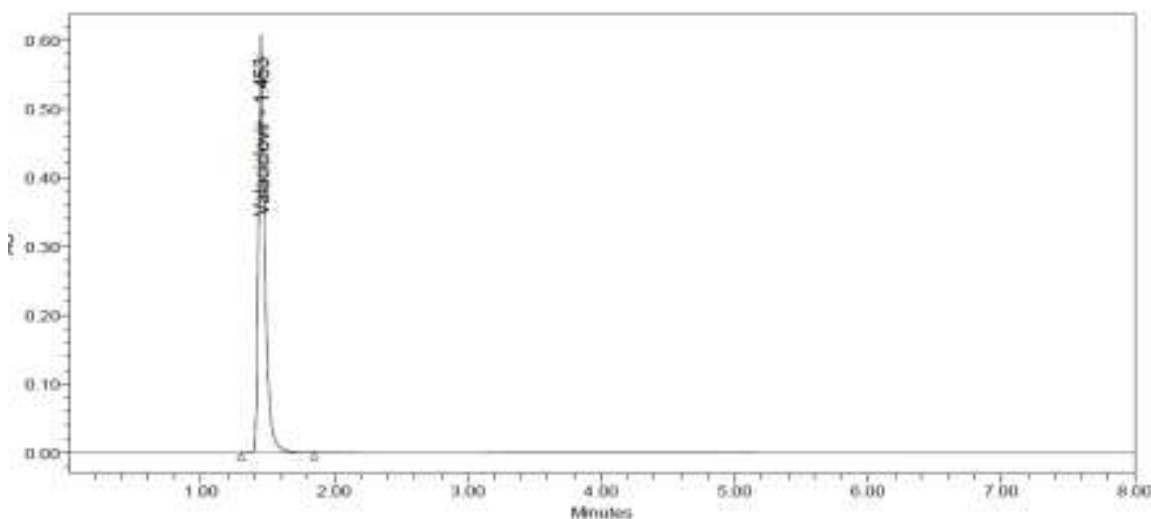

Fig:10. Chromatogram for Standard Mobilephase 60:40 using AcetoNitrile 


\section{ASSAY RESULTS:}

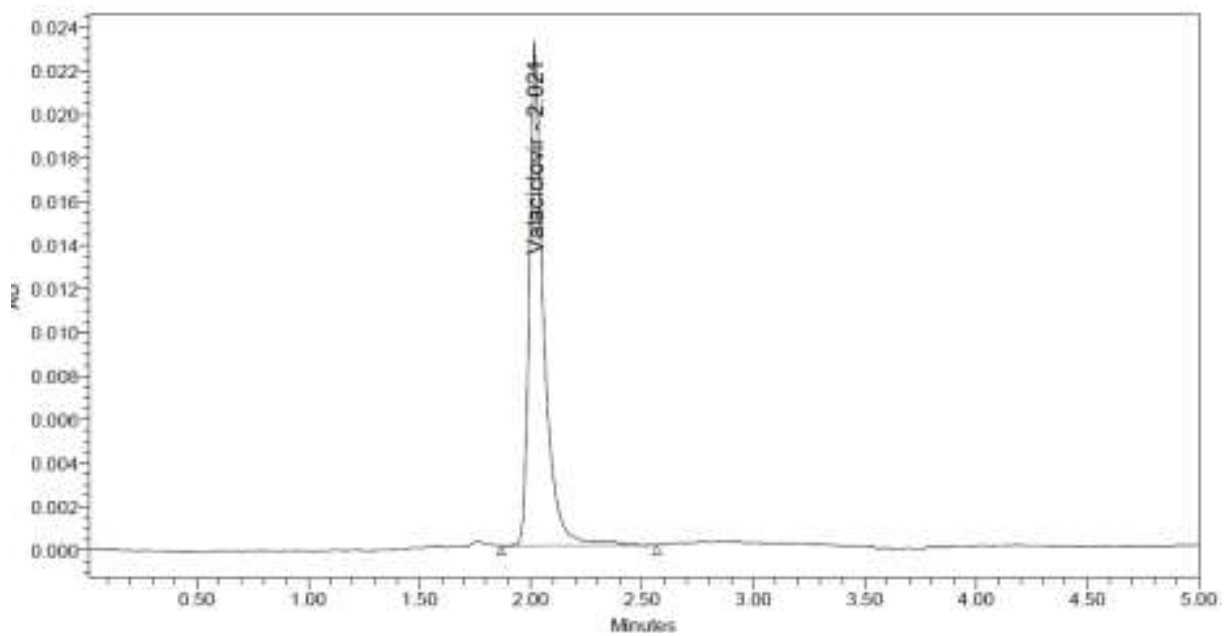

Fig: 11. Chromatogram for Sample 1 inj 1

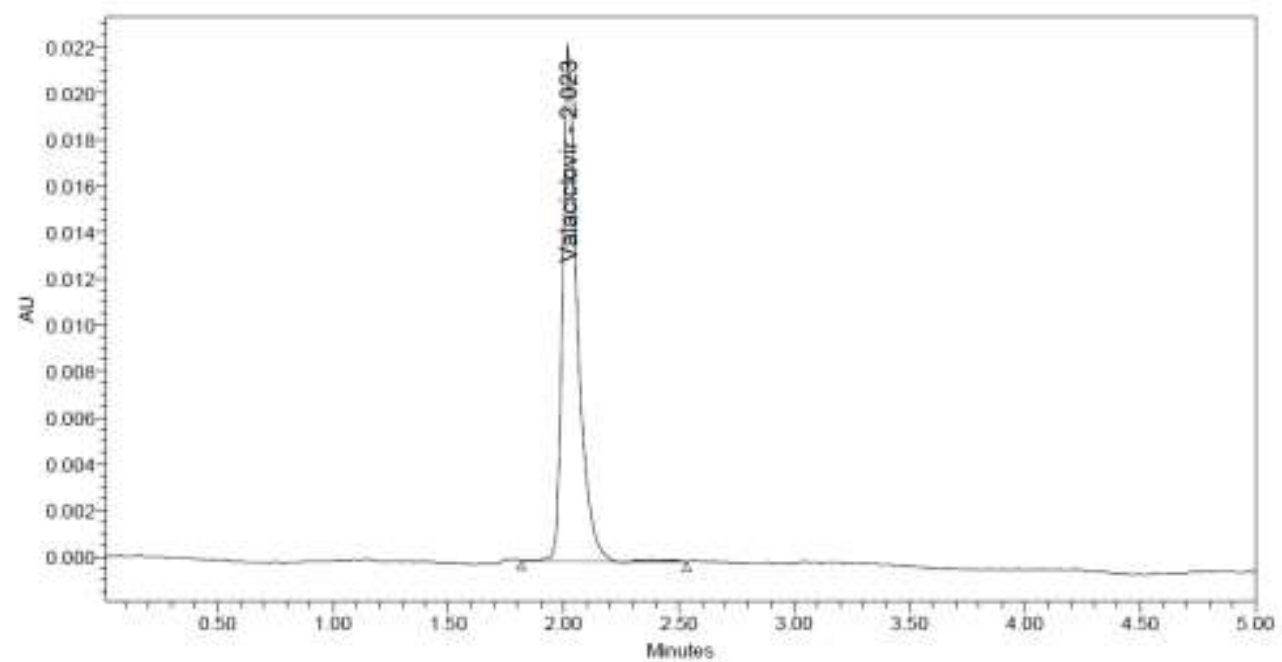

Fig12: Chromatogram for Sample 1 inj 2

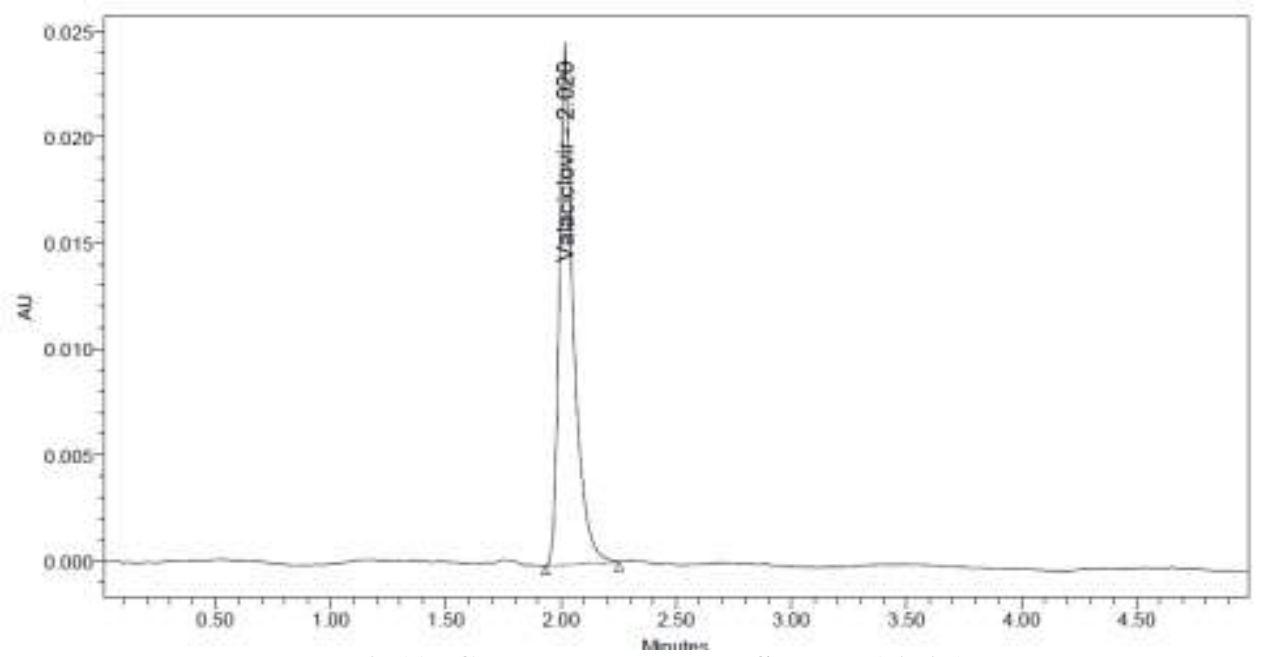

Fig13: Chromatogram For Sample 2 inj 1 


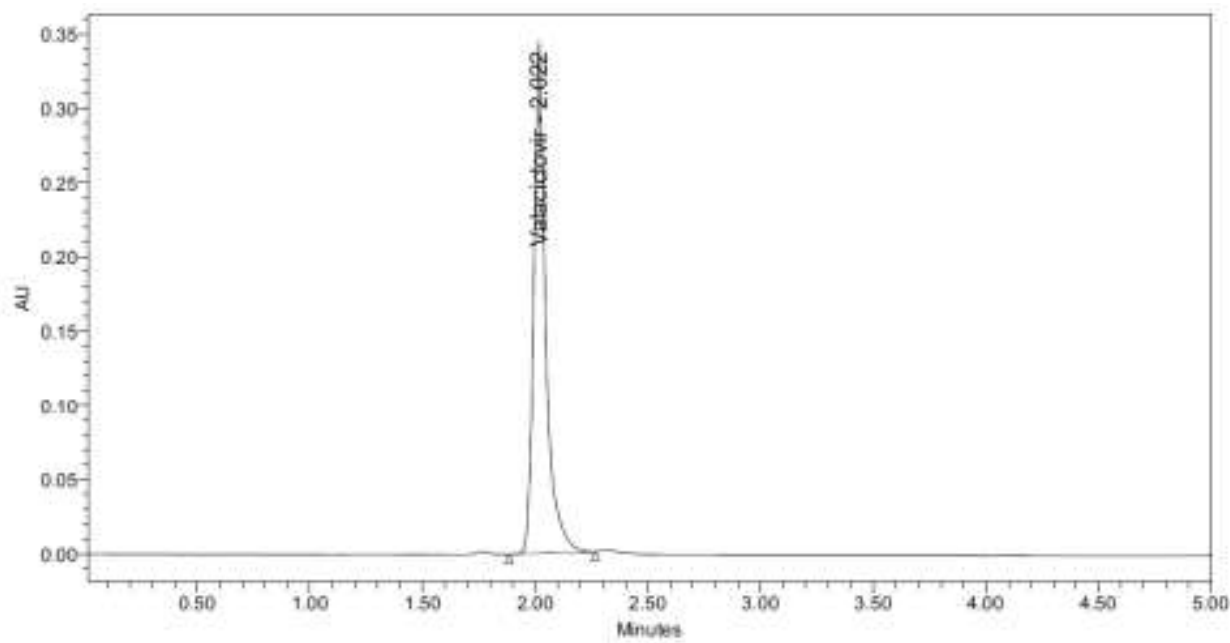

Fig14: Chromatogram for Sample 2 inj 2

Table 3: Assay Results for valacyclovir

\begin{tabular}{|l|l|l|l|l|}
\hline S.NO & Formulation & Label claim & Amount found & \% Assay \\
\hline 1 & Valcivir Tablets & 500 & 499.5 & 99.92 \\
\hline
\end{tabular}

Table: 4. Parameters for HPLC

\begin{tabular}{|l|l|}
\hline Instrument & WATERS 2695 HPLC Model \\
\hline Column & Agilent zorbax C8 $(150 x 4.6 \mathrm{~mm}, 5 \mu \mathrm{m})$ \\
\hline Wavelength & $253 \mathrm{~nm}$ \\
\hline Flow rate & $1 \mathrm{ml} / \mathrm{min}$ \\
\hline Injection volume & $5 \mu 1$ \\
\hline Mobile phase & Phosphate buffer : methanol $(50: 50 \mathrm{v} / \mathrm{v})$ \\
\hline Temperature & $25^{\circ} \mathrm{C}$ \\
\hline Run time & $5 \mathrm{~min}$ \\
\hline
\end{tabular}

\section{VALIDATION OF ANALYTICAL METHOD:}

Validation of an analytical method is the process to establish by laboratory studies that the performance characteristic of the method meets the requirements for the intended analytical application. Performance characteristics are expressed in terms of analytical parameters.

\section{Accuracy:}

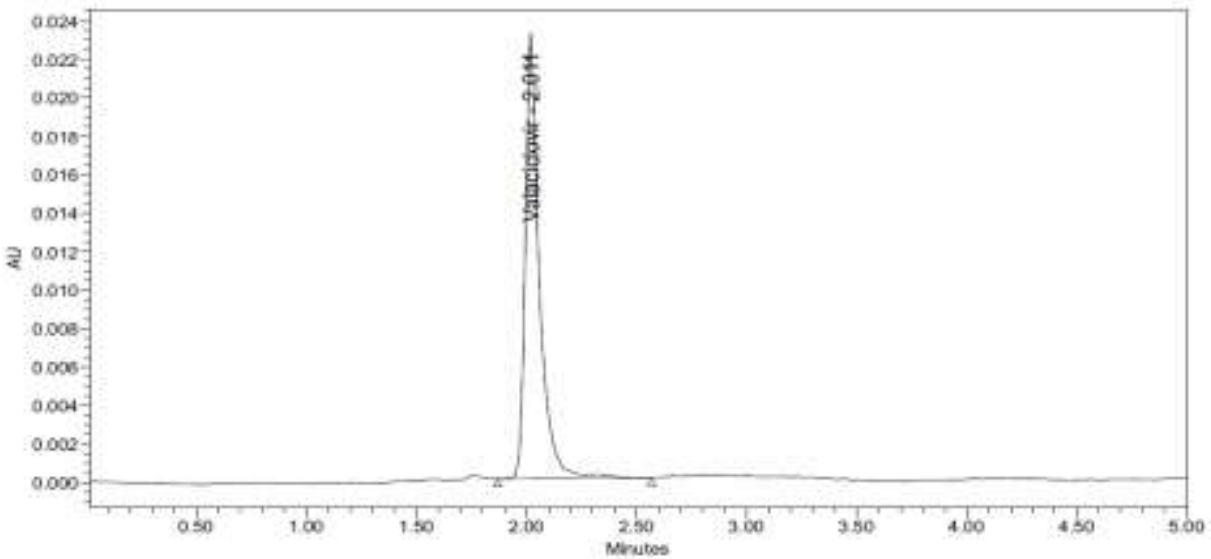

Fig 14. Chromatogram for Accuracy $50 \% 1^{\text {st }}$ injection 


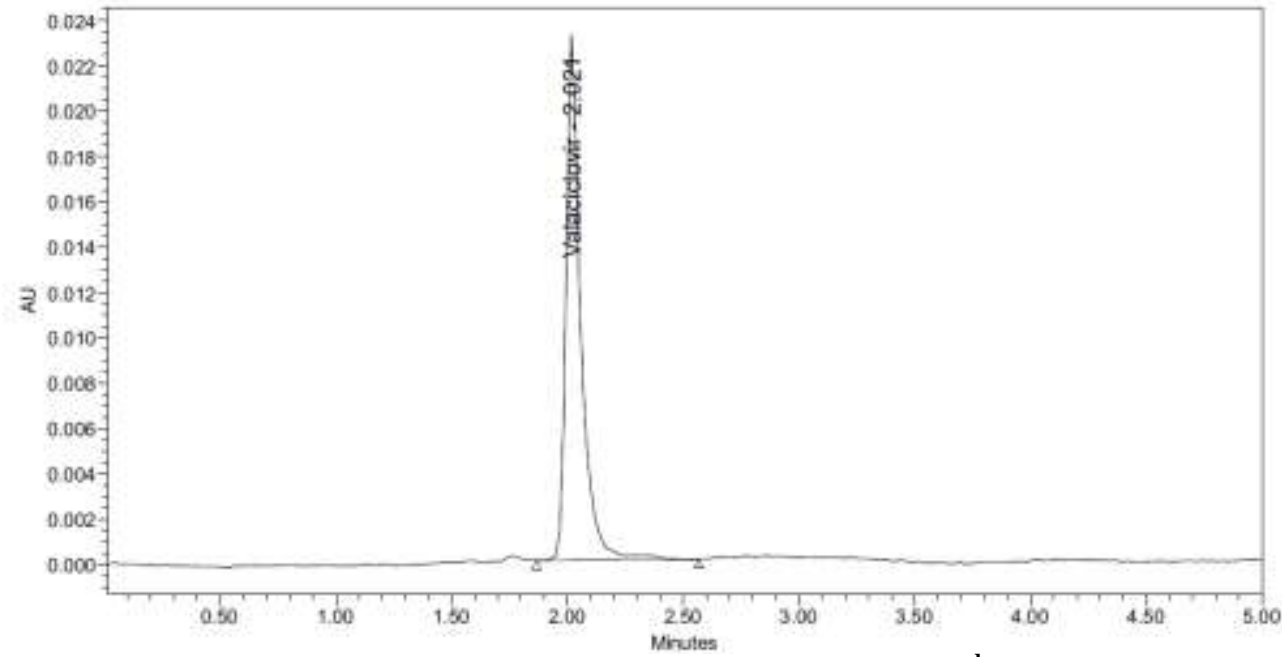

Fig 15. Chromatogram for Accuracy $50 \% 2^{\text {nd }}$ inj

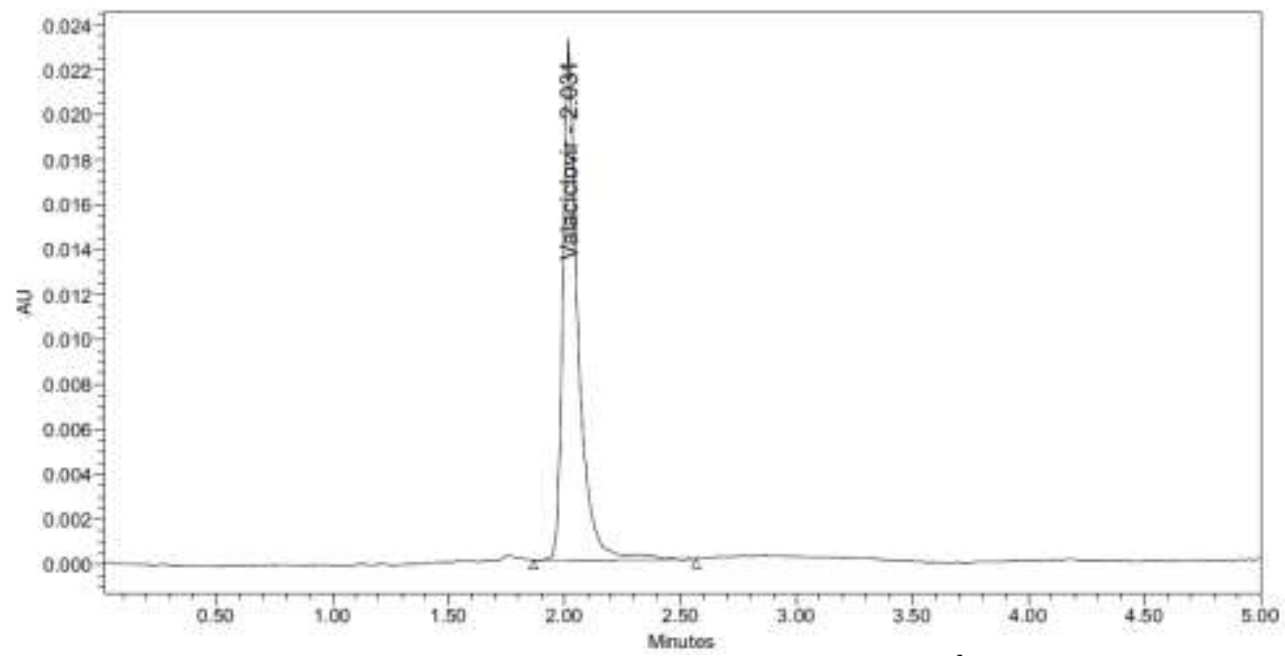

Fig 16. Chromatogram for Accuracy $50 \% 3^{\text {rd }}$ inj

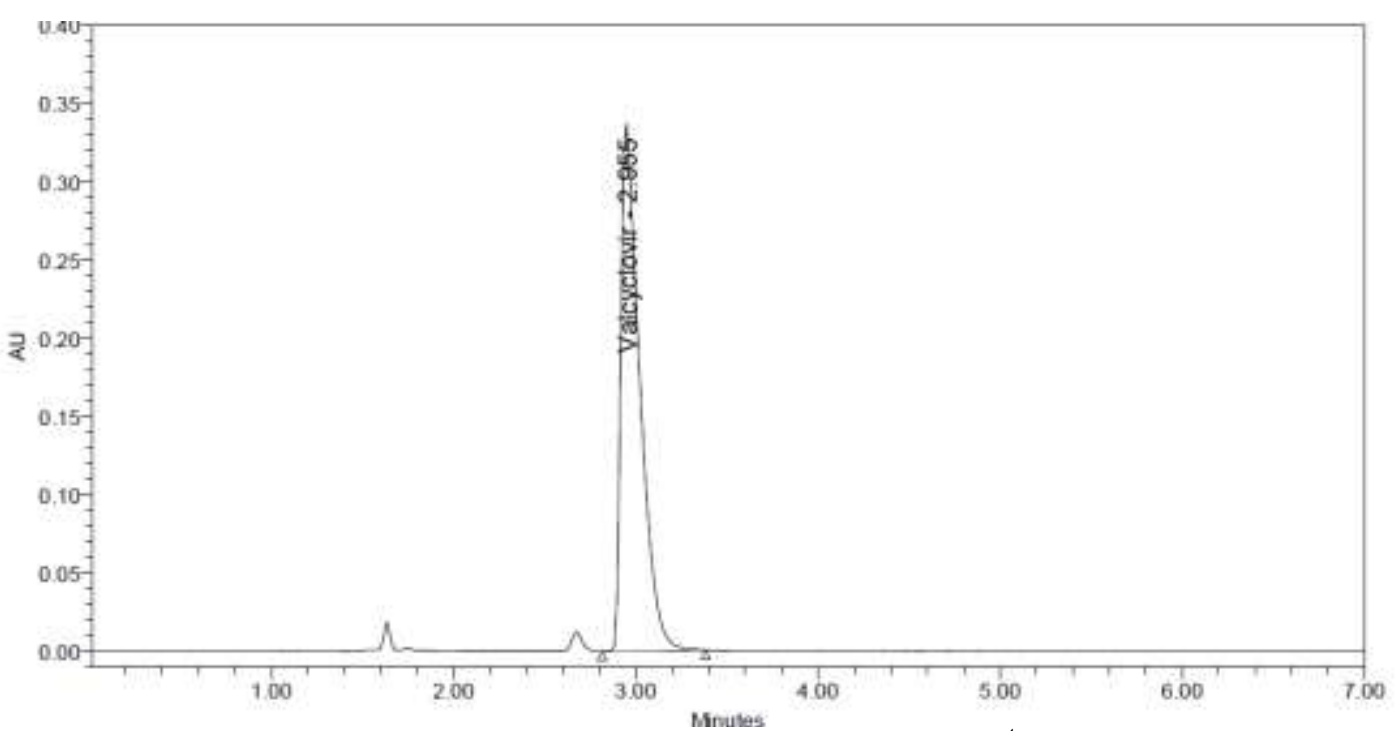

Fig 17. Chromatogram for Accuracy $100 \% 1^{\text {st }}$ inj 


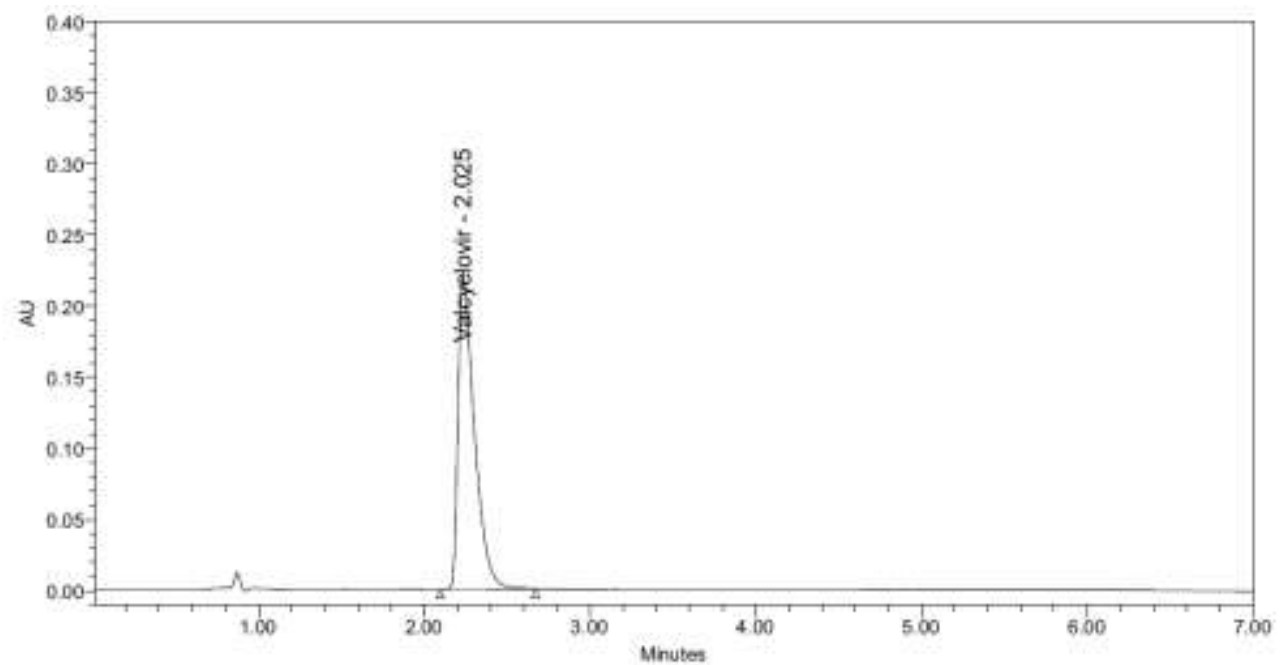

Fig 18. Chromatogram for Accuracy $100 \% 2^{\text {nd }}$ inj

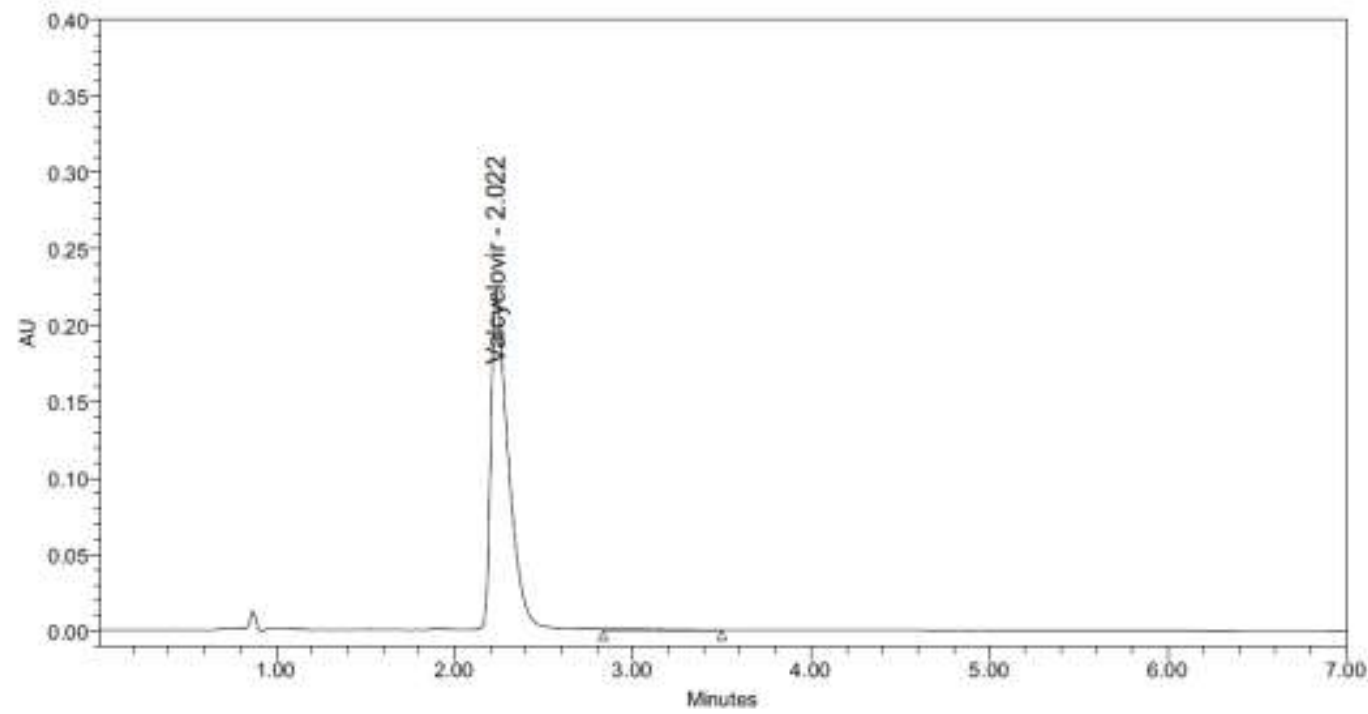

Fig 19. Chromatogram for Accuracy $100 \% 3^{\text {rd }}$ inj

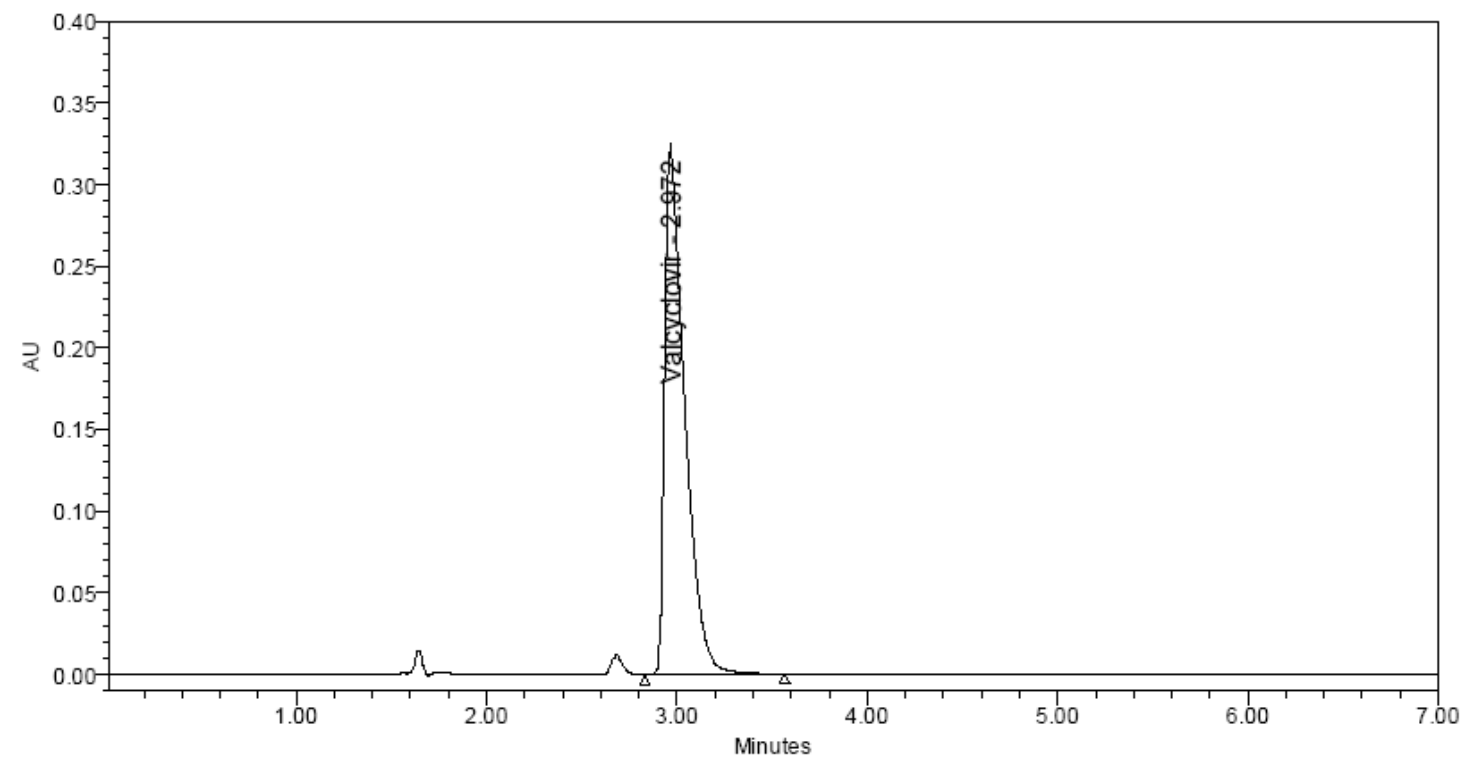

Fig 20. Chromatogram for Accuracy $150 \% 1^{\text {st }}$ inj 


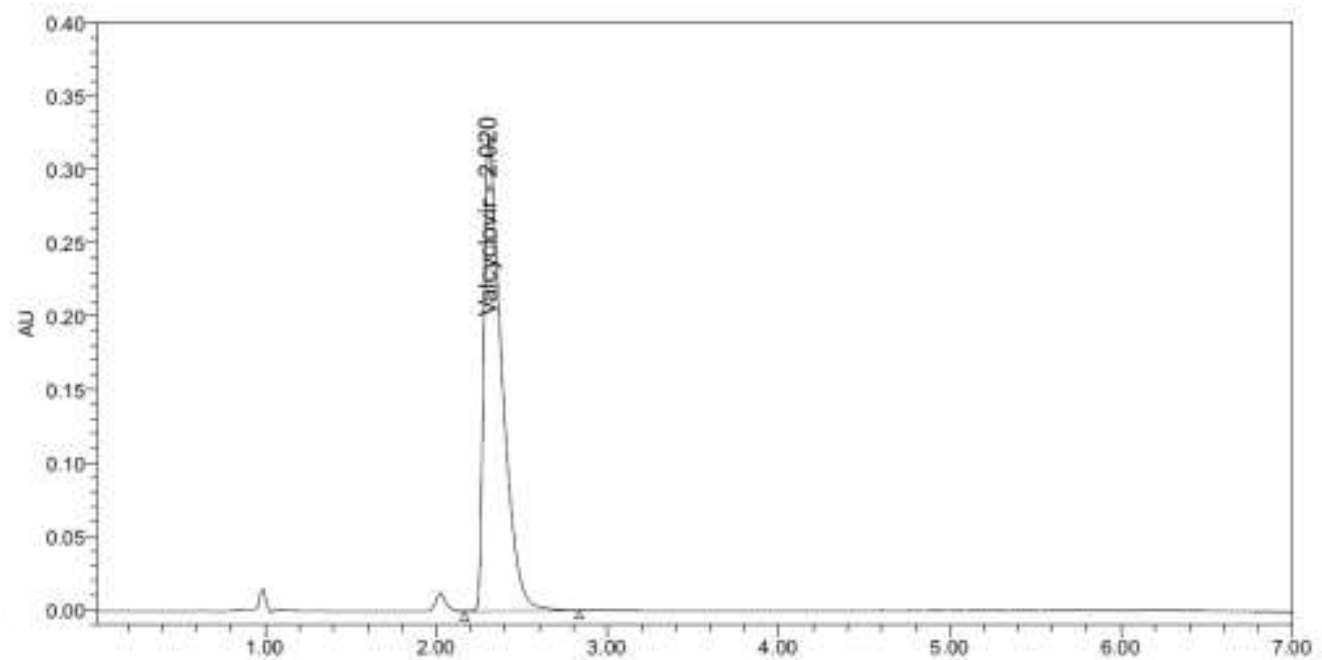

Fig 21. Chromatogram for Accuracy $150 \% 2^{\text {nd }}$ inj

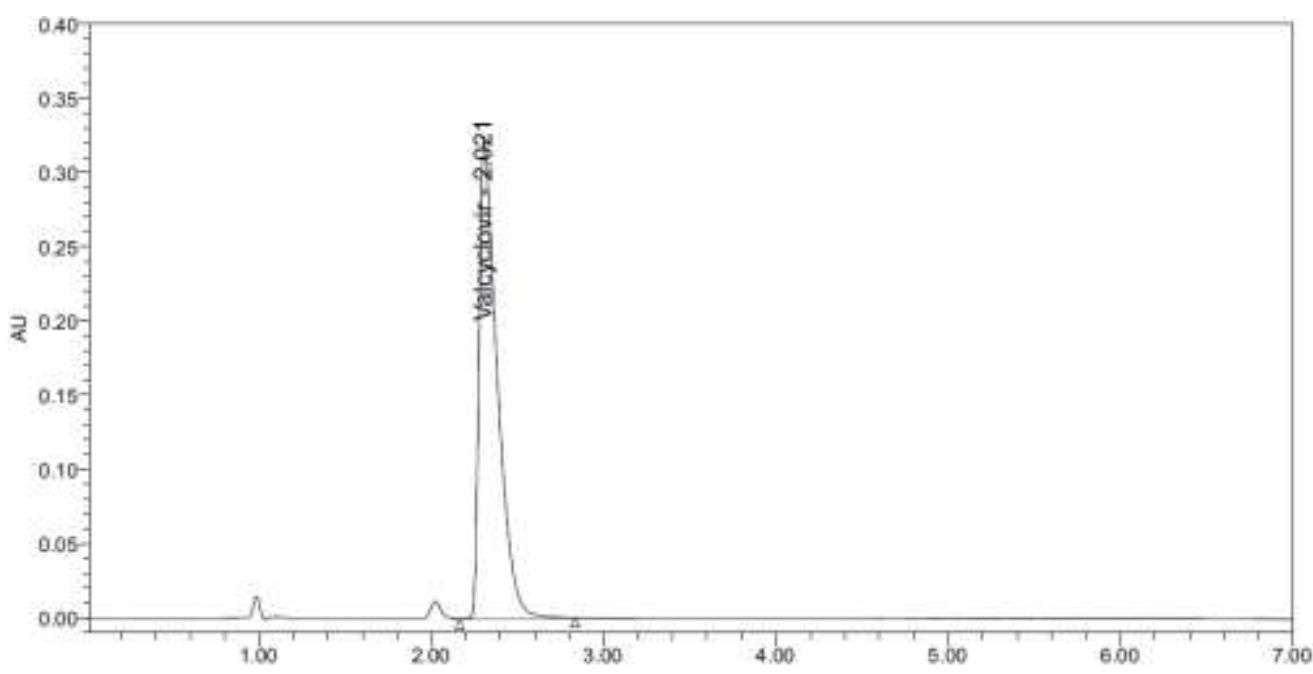

Fig 22. Chromatogram for Accuracy $150 \% 3^{\text {rd }}$ inj

Table: 5.Recovery studies for the proposed RP-HPLC method

\begin{tabular}{|c|c|c|c|c|c|}
\hline Drug & \% Level & $\begin{array}{c}\text { Amount Added } \\
(\mathbf{m g})\end{array}$ & $\begin{array}{c}\text { Amount Found } \\
(\mathbf{m g})\end{array}$ & \% Recovery & $\begin{array}{c}\text { Mean } \\
\text { Recovery** }\end{array}$ \\
\hline \multirow{3}{*}{ Valacyclovir } & 50 & 50 & 101 & 99.8 & \\
\cline { 2 - 5 } & 50 & 100 & 148 & 99.5 & \multirow{2}{*}{99.7} \\
\cline { 2 - 5 } & 50 & 150 & 201 & 99.8 & \\
\hline
\end{tabular}

**Average of three determinations

The RP-HPLC method developed in the present study has been used to quantify valacyclovir in tablet formulations. valcivir $(500 \mathrm{mg})$ film coated tablets were analyzed as per the procedure described above. The mean recoveries were found in the range of 99.5-99.8\%. The results are presented in Table 5. No interfering peaks were found in the chromatogram indicating that Excipients usually present in the tablet formulation did not interfere with the estimation of the drug by the proposed RP-HPLC method.

\section{PRECISION}

The precision of the analytical method was studied by analysis of multiple sampling of homogeneous sample. The precision results were expressed as standard deviation or Relative standard Deviation

A. System Precision or System suitability

B. Method Precision 
A. System Precision or System Suitability

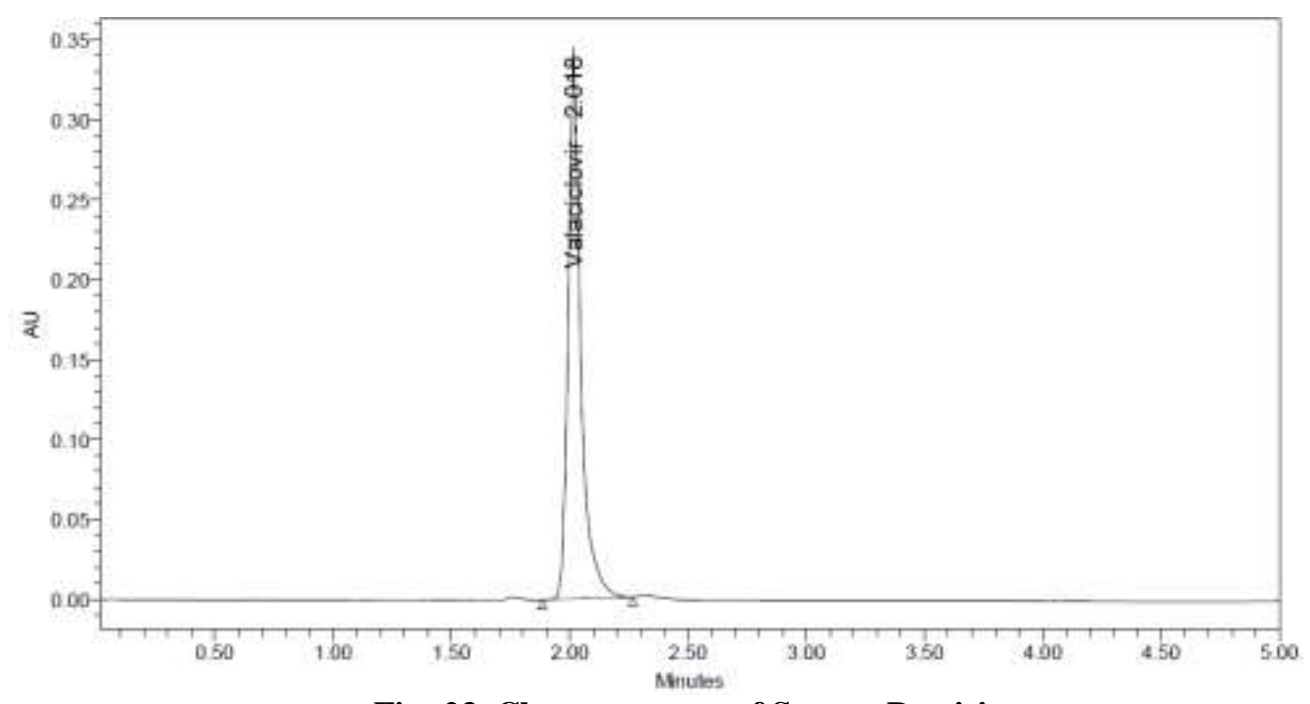

Fig: 23. Chromatogram of System Precision

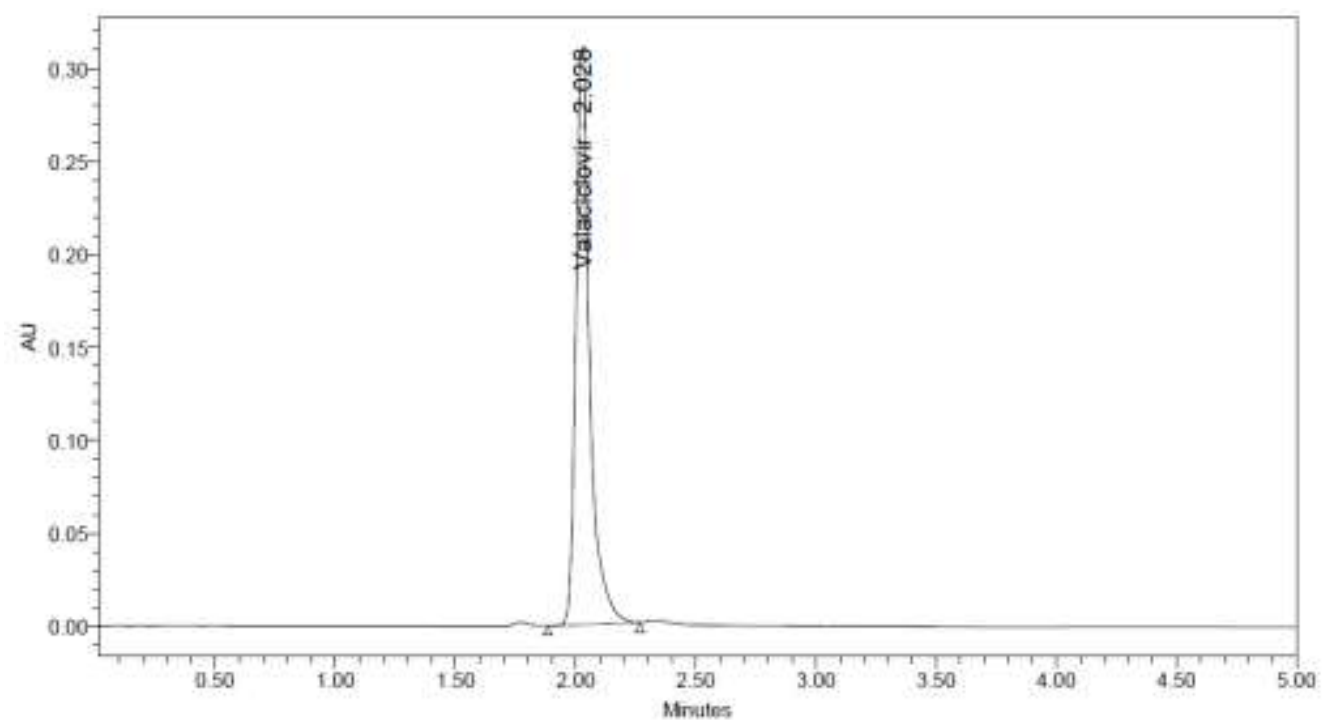

Fig 24.Chromatogram for System Precision

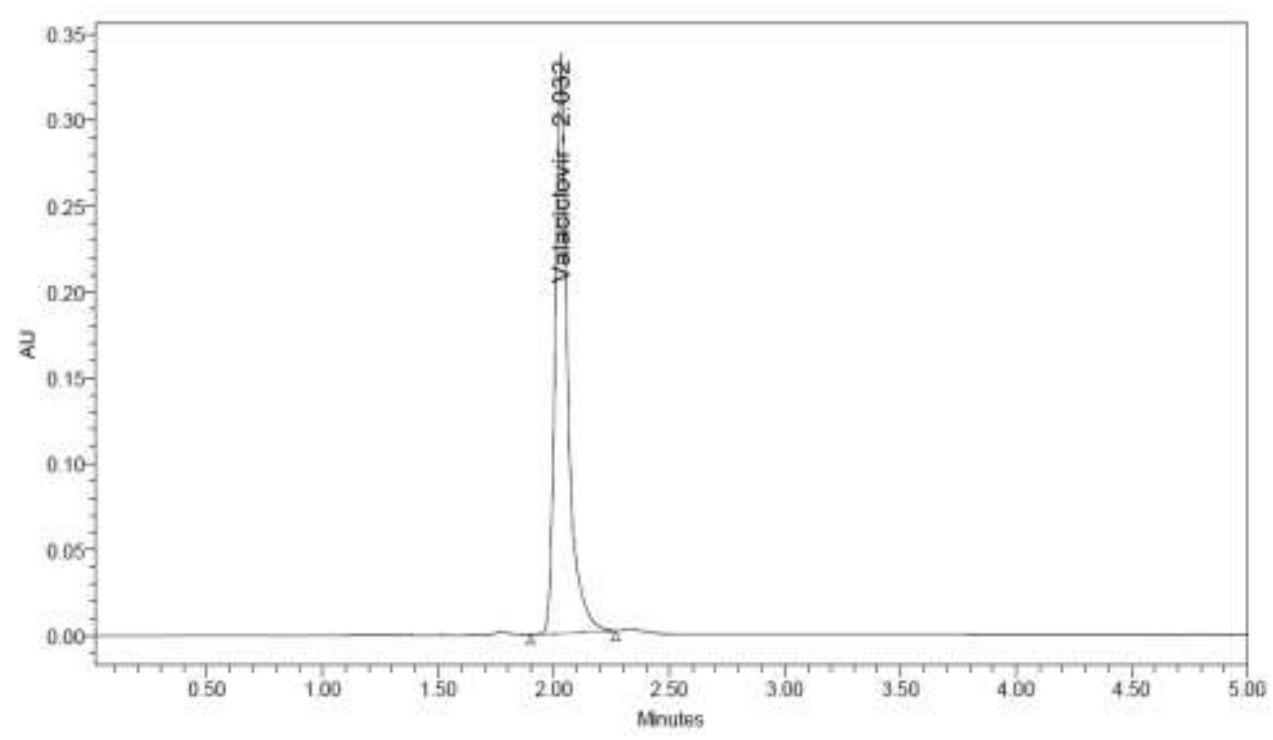

Fig 25.Chromatogram for System Precision 


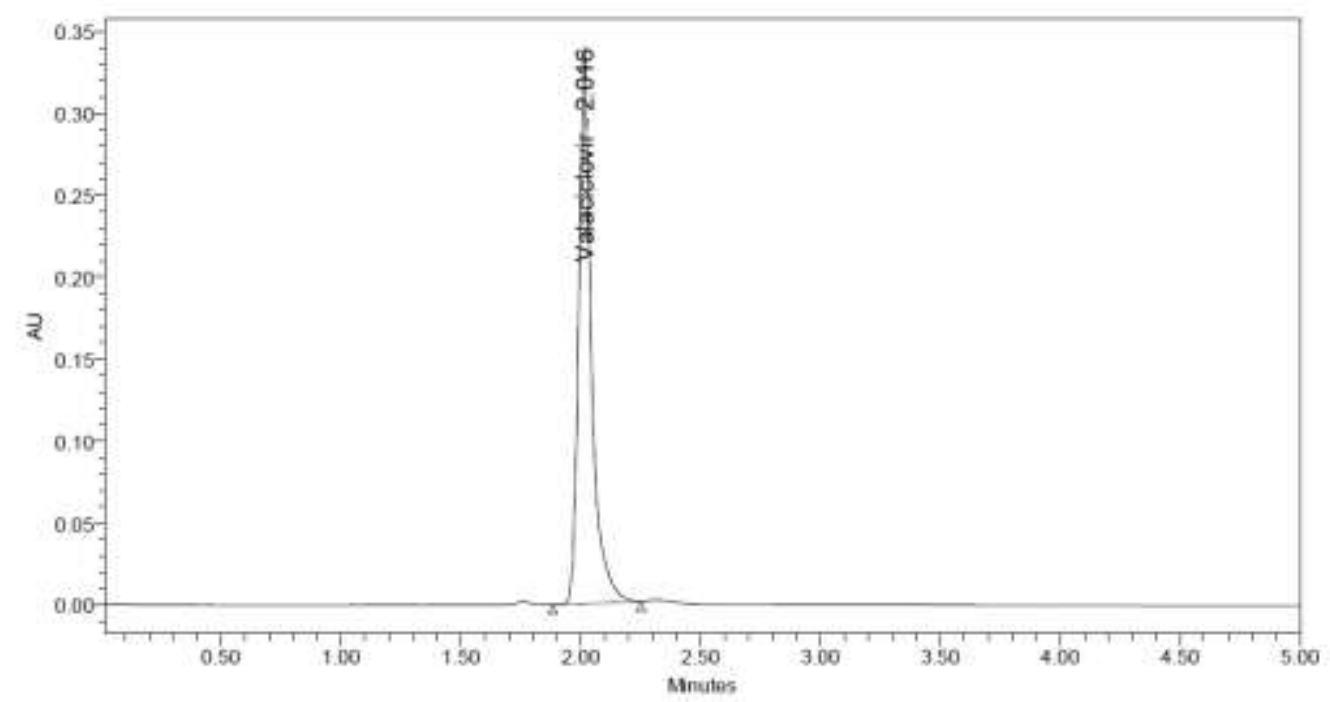

Fig 27.Chromatogram for System Precision

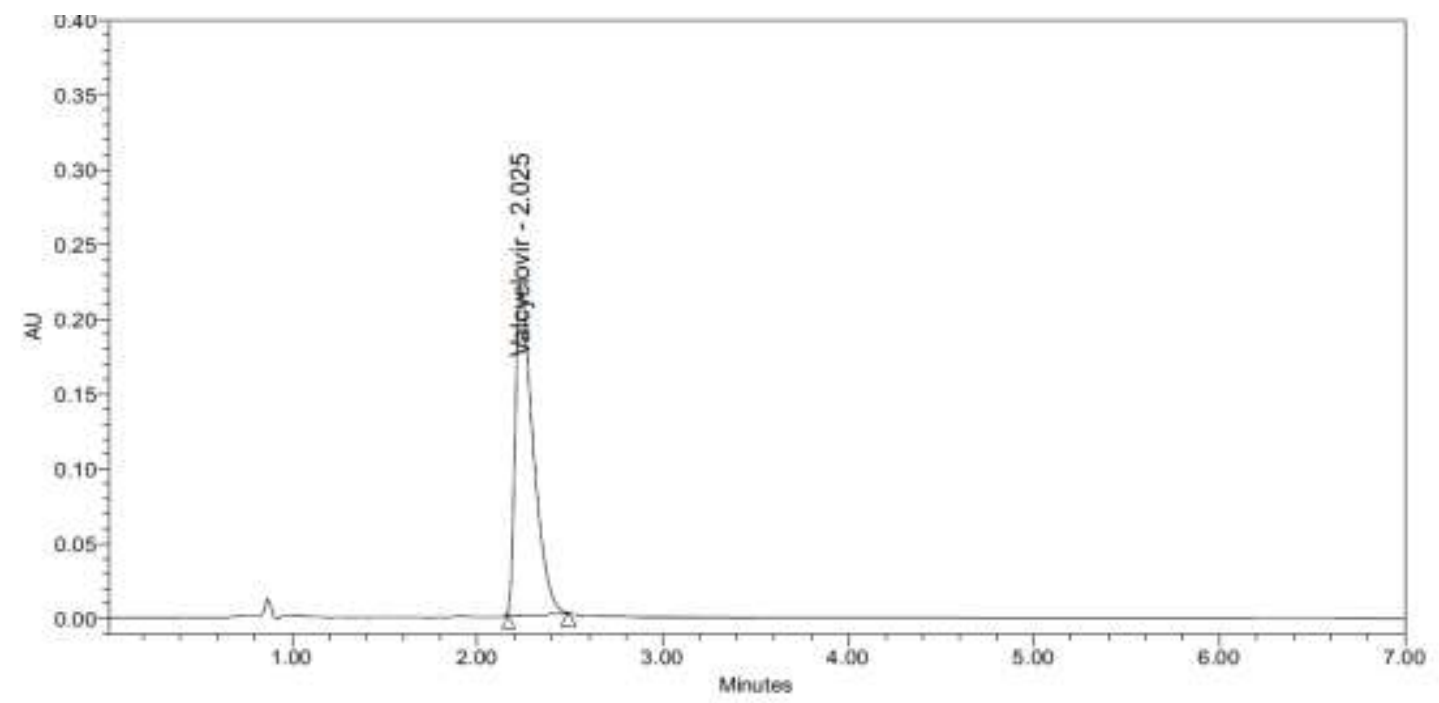

Fig 28.Chromatogram for System Precision

Table: 6. System precision results for valacyclovir

\begin{tabular}{|c|c|c|c|c|}
\hline S,No & Rt & Peak area & Tailing factor & Theoritical plates \\
\hline 1 & 2.018 & 1256384 & 1.3 & 4591 \\
\hline 2 & 2.018 & 1265378 & 1.3 & 4557 \\
\hline 3 & 2.025 & 1256384 & 1.3 & 4705 \\
\hline 4 & 2.028 & 1245681 & 1.3 & 4594 \\
\hline 5 & 2.032 & 1247911 & 1.3 & 4565 \\
\hline 6 & 2.016 & 1244209 & 1.3 & 4648 \\
\hline Mean & 2.021 & 1251158.83 & 1.3 & 4610 \\
\hline SD & 0.006623192 & 8150.615 & & \\
\hline$\%$ RSD & 0.0032771 & 0.0065144 & & \\
\hline
\end{tabular}

Acceptance Criteria: Tailing factor $<2$

Plate Count $>2000$

$\%$ RSD - NMT 2 


\section{B. Method Precision}

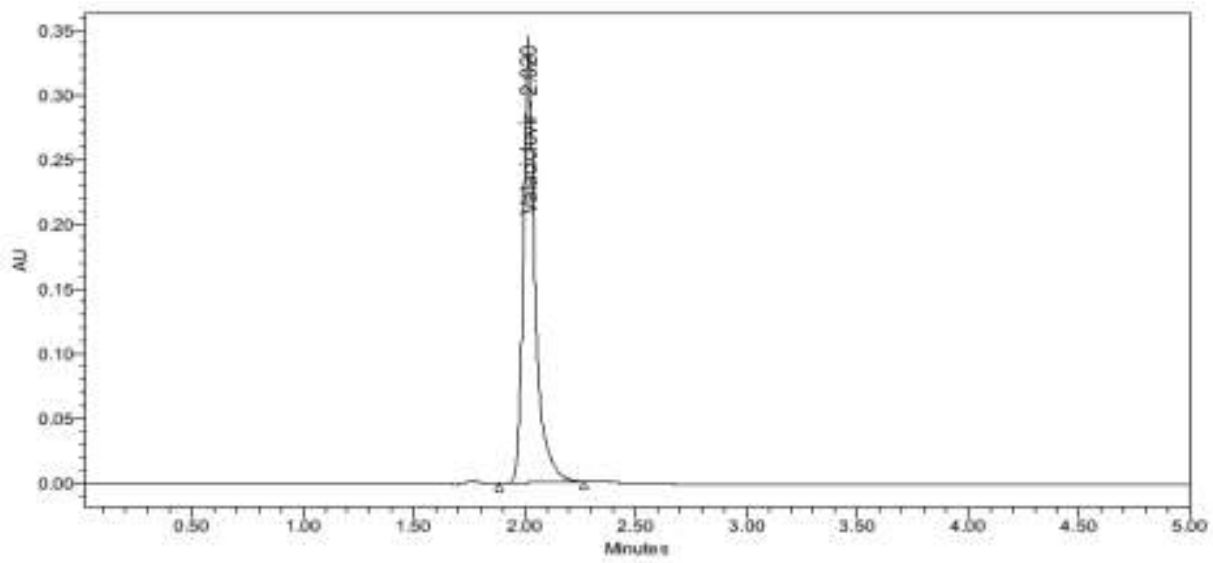

Fig: 29. Chromatogram of Method Precision (Intraday)

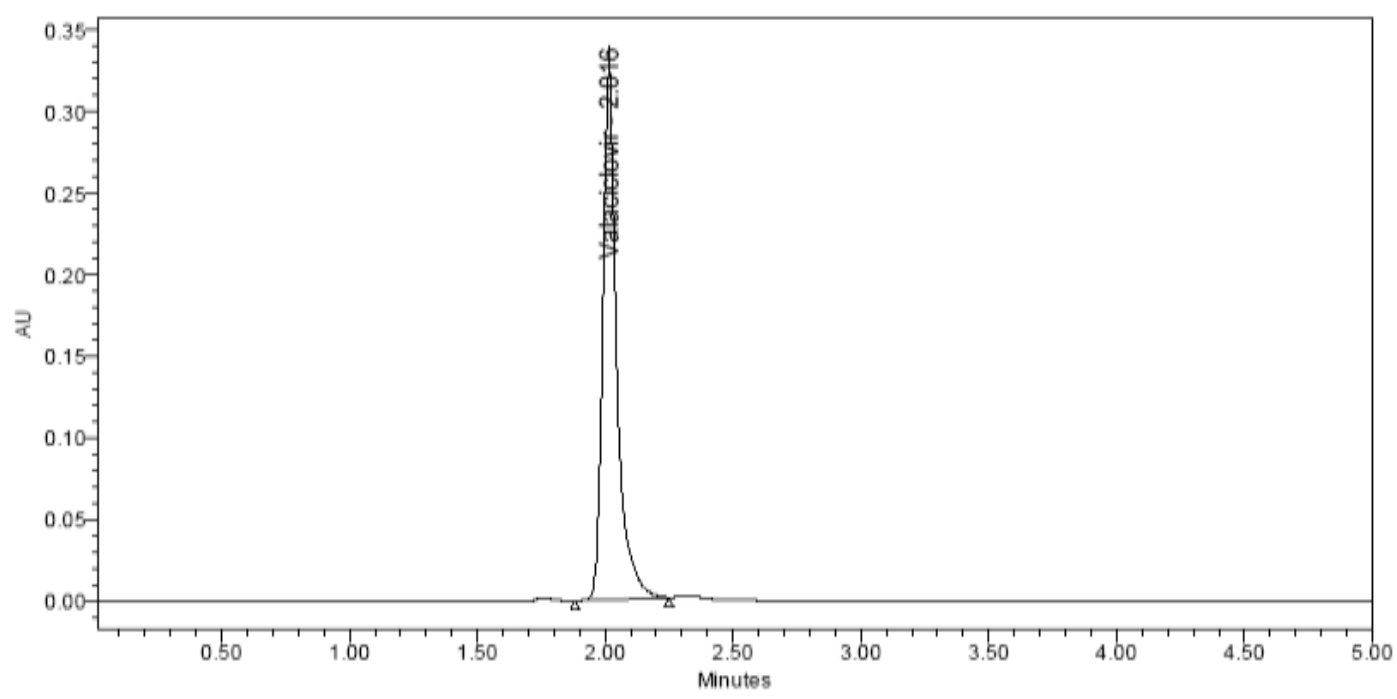

Fig: 30. Chromatogram of Method Precision (Interday)

Table: 7. Method Precision results for valacyclovir

\begin{tabular}{|l|l|l|l|}
\hline SL.No. & Conc & Intra day & interday \\
\hline 1 & 100 & 1258290 & 1233072 \\
\hline 2 & 100 & 1267124 & 1204813 \\
\hline 3 & 100 & 1255318 & 1243218 \\
4 & 100 & 1242958 & 1230047 \\
\hline 5 & 100 & 1262952 & 1245832 \\
\hline 6 & 100 & 1262575 & 1254460 \\
\hline Avg & & 1258202.833 & 1235240.333 \\
\hline SD & & 8508.730162 & 17336.18845 \\
\hline$\%$ RSD & & 0.6762 & 1.40 \\
\hline
\end{tabular}

The precision of the method was demonstrated by intra-day and inter-day precision studies. Intraday studies were performed by injecting six (6) repeated injections of $100 \%$ concentration from tablet solution within a day. Peak area and \%RSD were calculated and reported in Table7-. The chromatograms of intra-day precision studies were shown in Fig29. Inter-day precision studies, was done by injecting six (6) repeated injections of $100 \%$ concentration from tablet solution for six consecutive days. Peak area and \%RSD were calculated and 
reported in Table-7. The chromatograms of inter-day precision studies were shown in Fig.30. The \% RSD values were within 2 and the method was found to be precise.

\section{Linearity:}

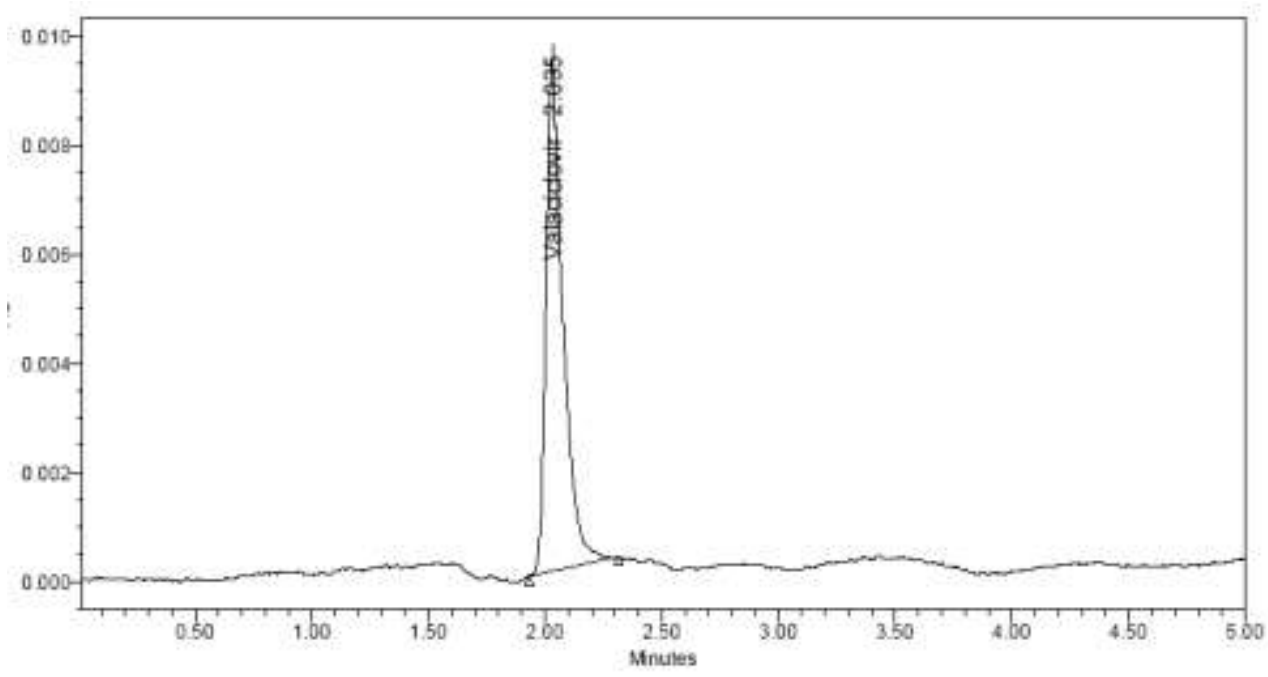

Fig: 31. Chromatogram of $20 \mu \mathrm{g} / \mathrm{ml}$ of valacyclovir

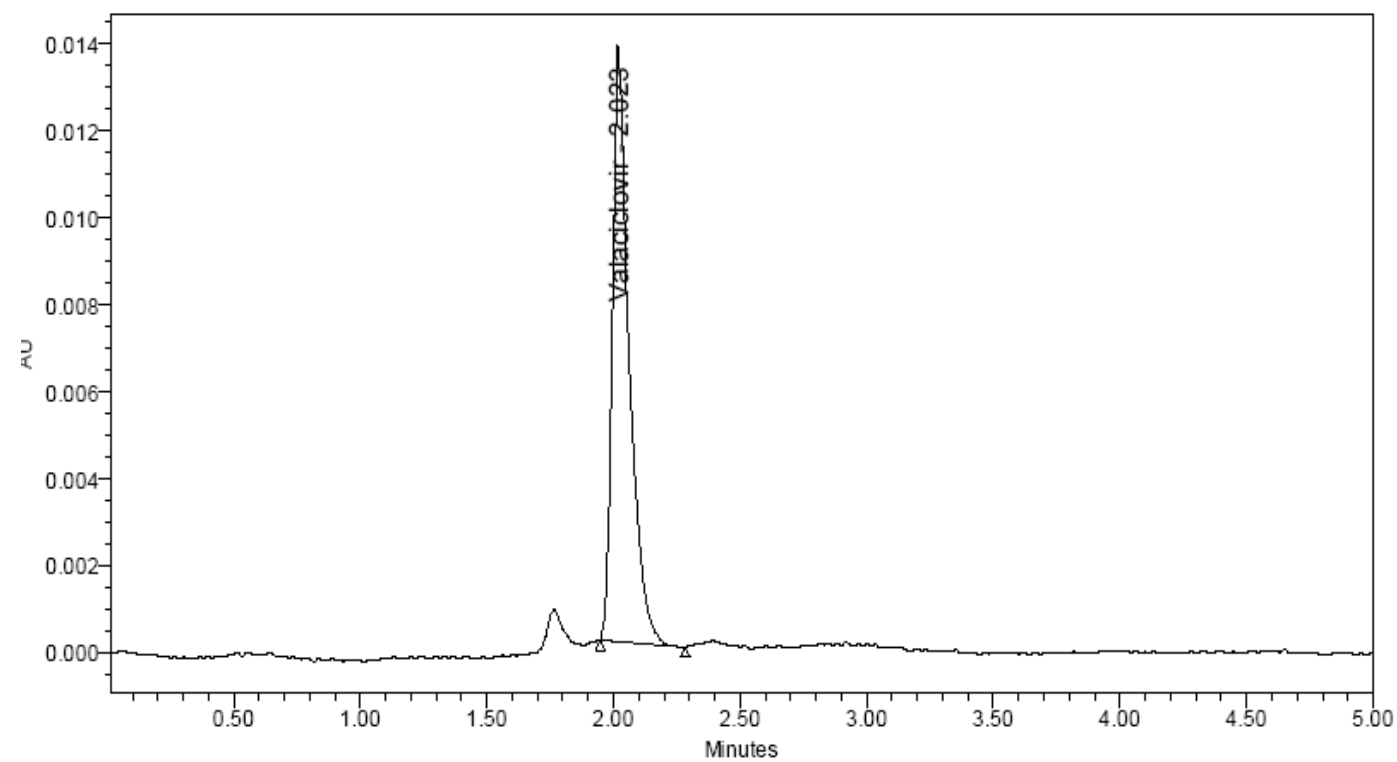

Fig: 32. Chromatogram of $50 \mu \mathrm{g} / \mathrm{ml}$ of valacyclovir

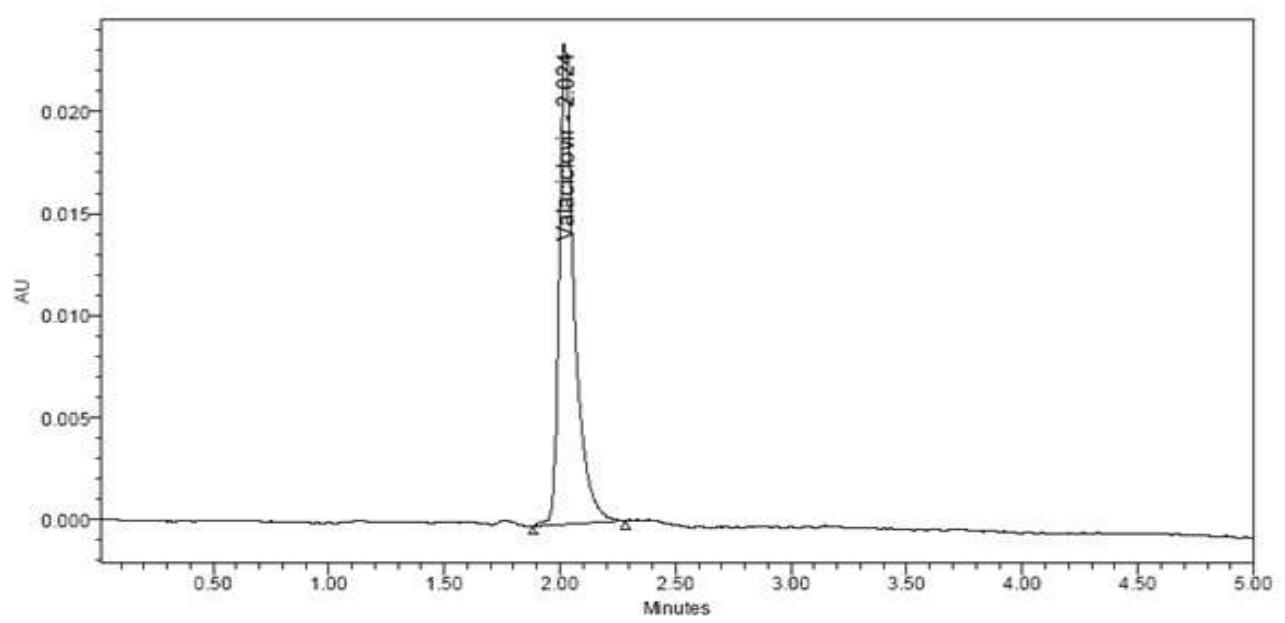

Fig: 33. Chromatogram of $100 \mu \mathrm{g} / \mathrm{ml}$ of valcyclovir 


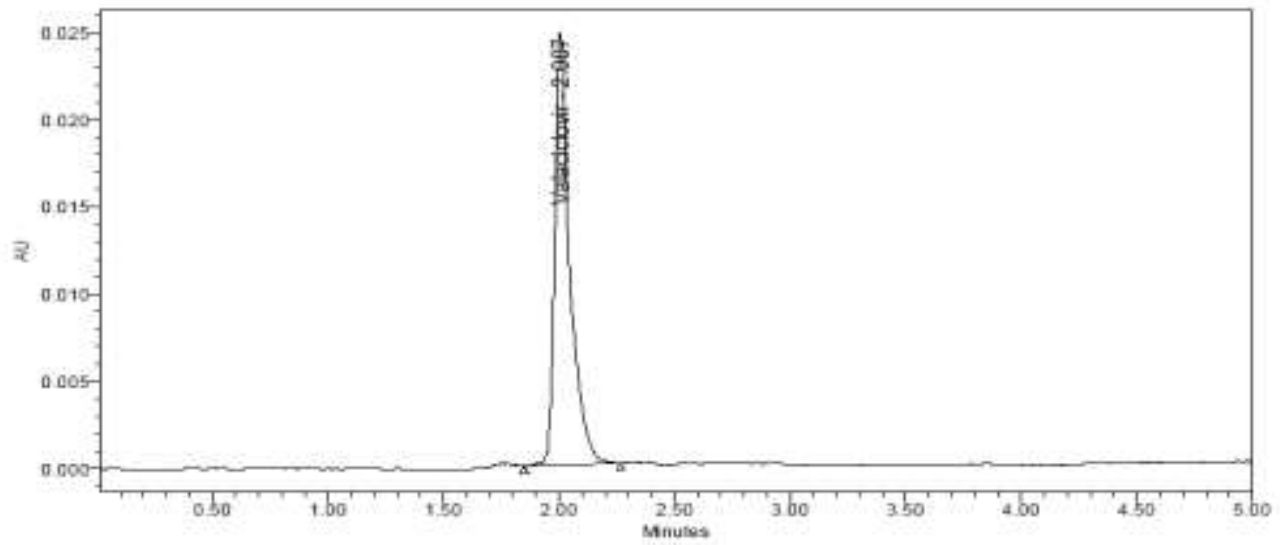

Fig: 34. Chromatogram of $120 \mu \mathrm{g} / \mathrm{ml}$ of valacyclovir

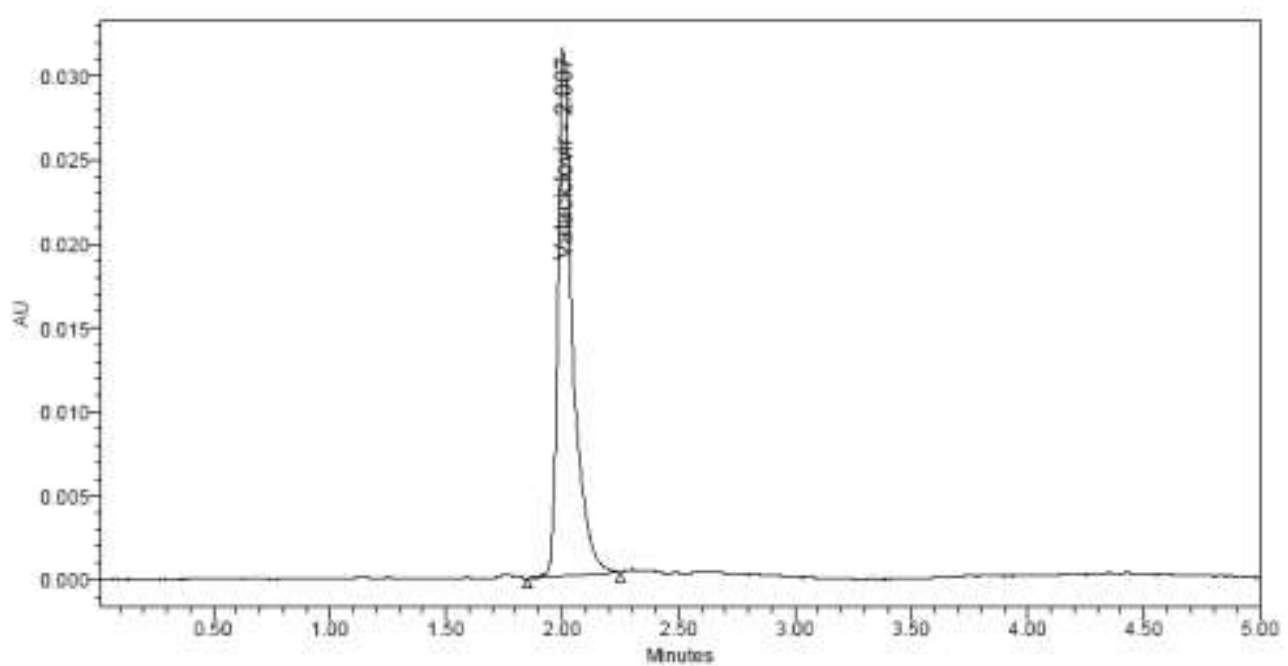

Fig: 35. Chromatogram of $150 \mu \mathrm{g} / \mathrm{ml}$ of valacyclovir

Table: 8. Linearity results for valacyclovir

\begin{tabular}{|c|c|c|}
\hline SL.NO & Linearity Level $(\%)$ & Peak Area \\
\hline 1 & 20 & 25027 \\
\hline 2 & 50 & 49999 \\
\hline 3 & 100 & 94684 \\
\hline 4 & 120 & 112000 \\
\hline 5 & 150 & 138046 \\
\hline
\end{tabular}

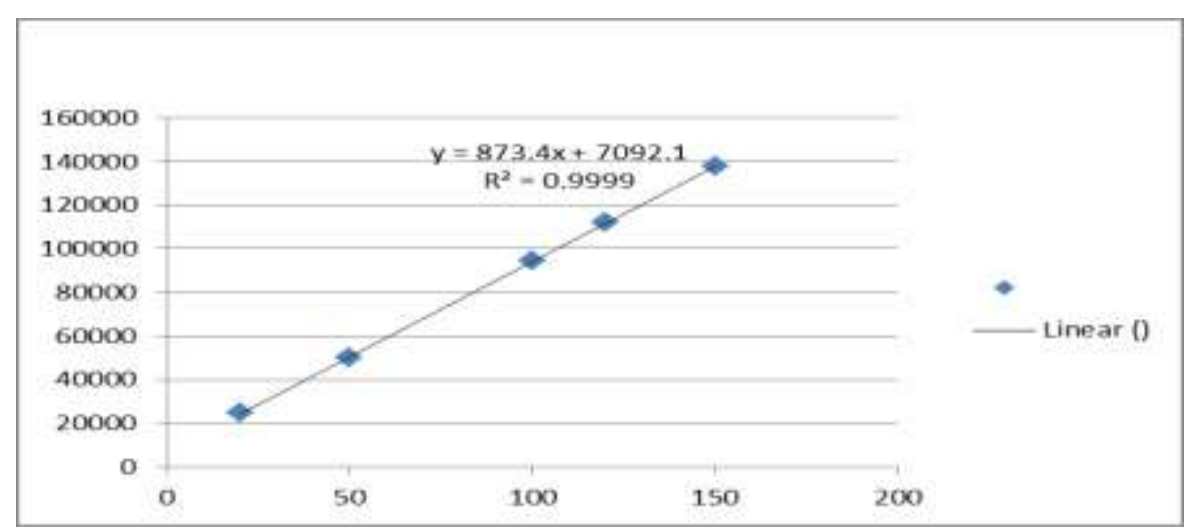

Fig: 36. Calibration curve of Val acyclovir at $253 \mathrm{~nm}$ 
Table: 9. Calibration parameters of valacyclovir

\begin{tabular}{|l|l|}
\hline Parameters & Results \\
\hline Slope & 873.4 \\
\hline Intercept & 7092.1 \\
\hline Correlation co-efficient & 0.9999 \\
\hline
\end{tabular}

\section{Robustness}

The robustness of an analytical procedure is a measure of its capacity to remain unaffected by small, but deliberate variations in method parameters and provides an indication of its reliability during normal usage.

(A) Effect of flow Rate:

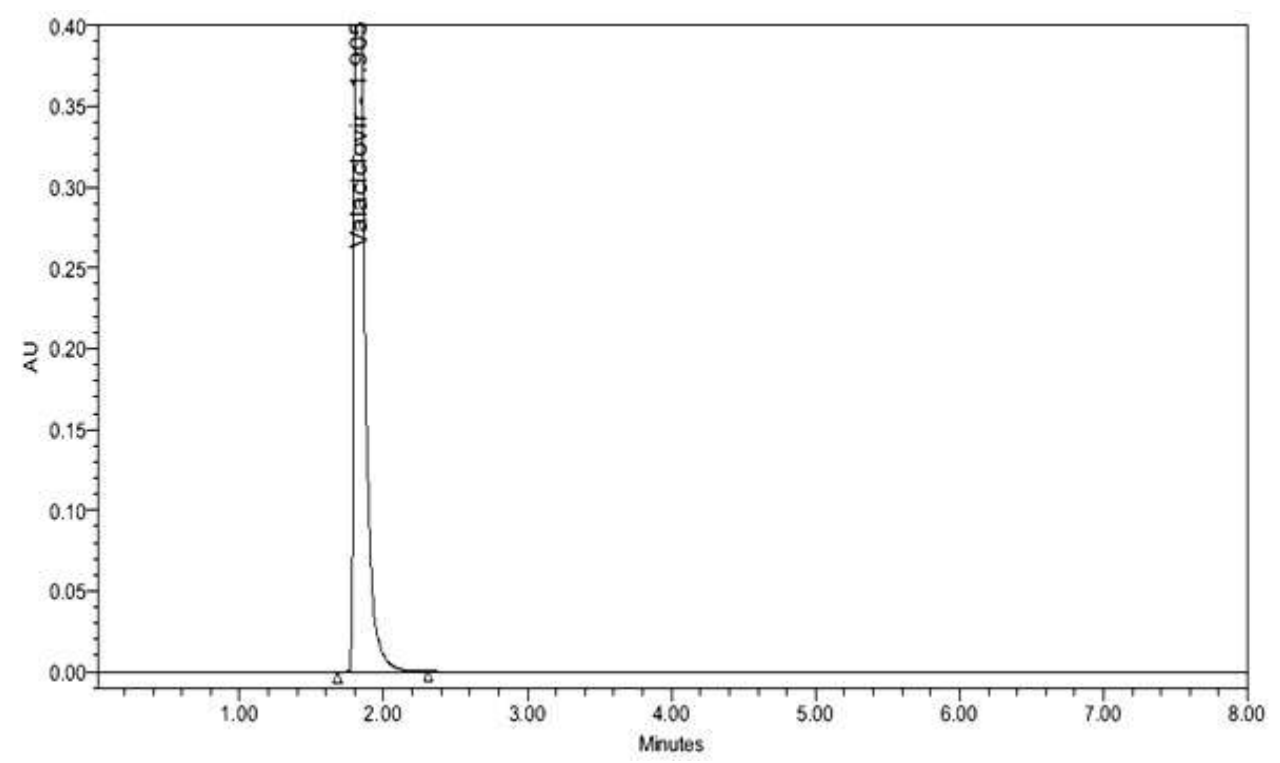

Fig.37. Chromatogram of Robustness (More flow rate)

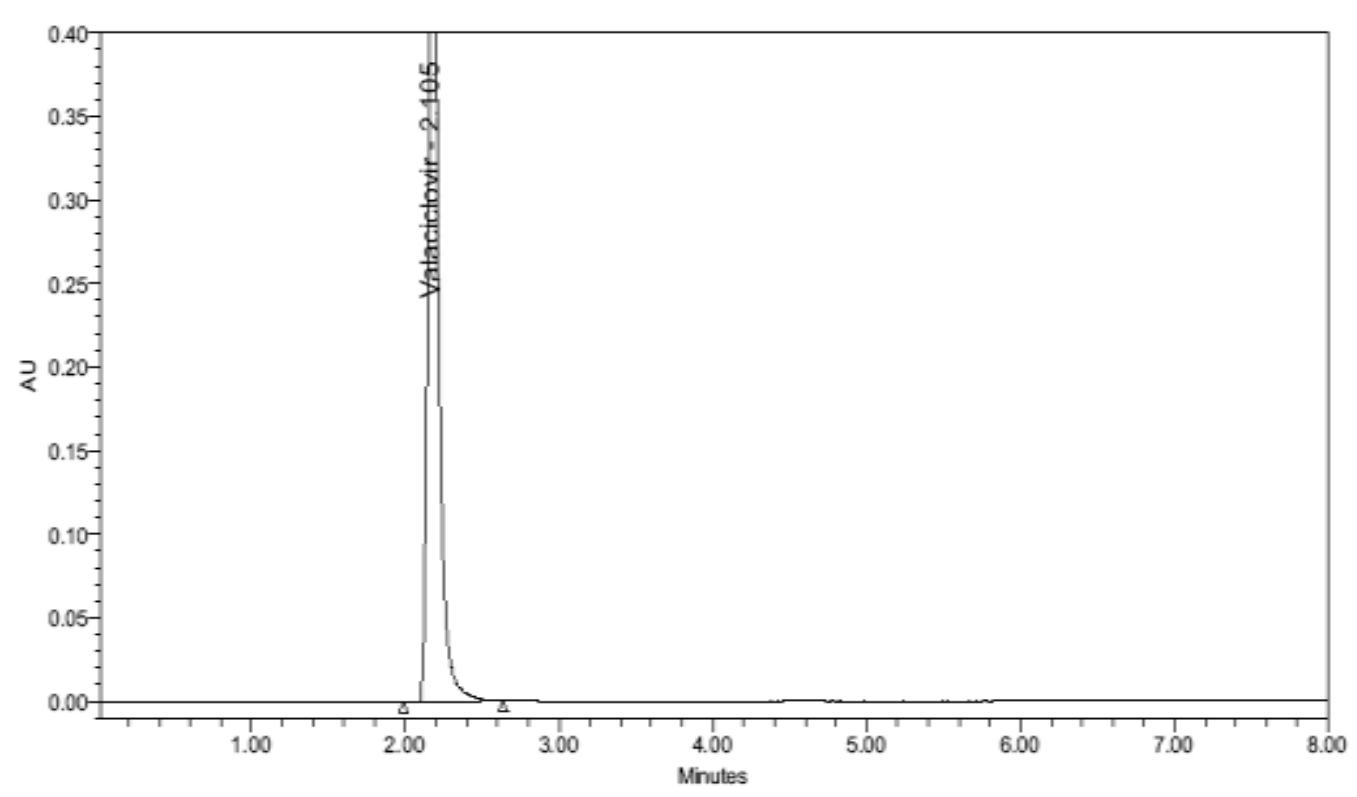

Fig.38.Chromatogram of Robustness (Less Flow rate) 
Table: 10. Robustness Flowrate results for valacyclovir

\begin{tabular}{|c|c|c|c|}
\hline Flowrate(ml/min) & Retention Time & Tailing Factor & USP Plate Count \\
\hline 0.8 & 3.342 & 1.3 & 4874 \\
\hline 1 & 2.105 & 1.3 & 4827 \\
\hline 1.2 & 1.915 & 1.3 & 4435 \\
\hline
\end{tabular}

(B) Effect of Temperature:

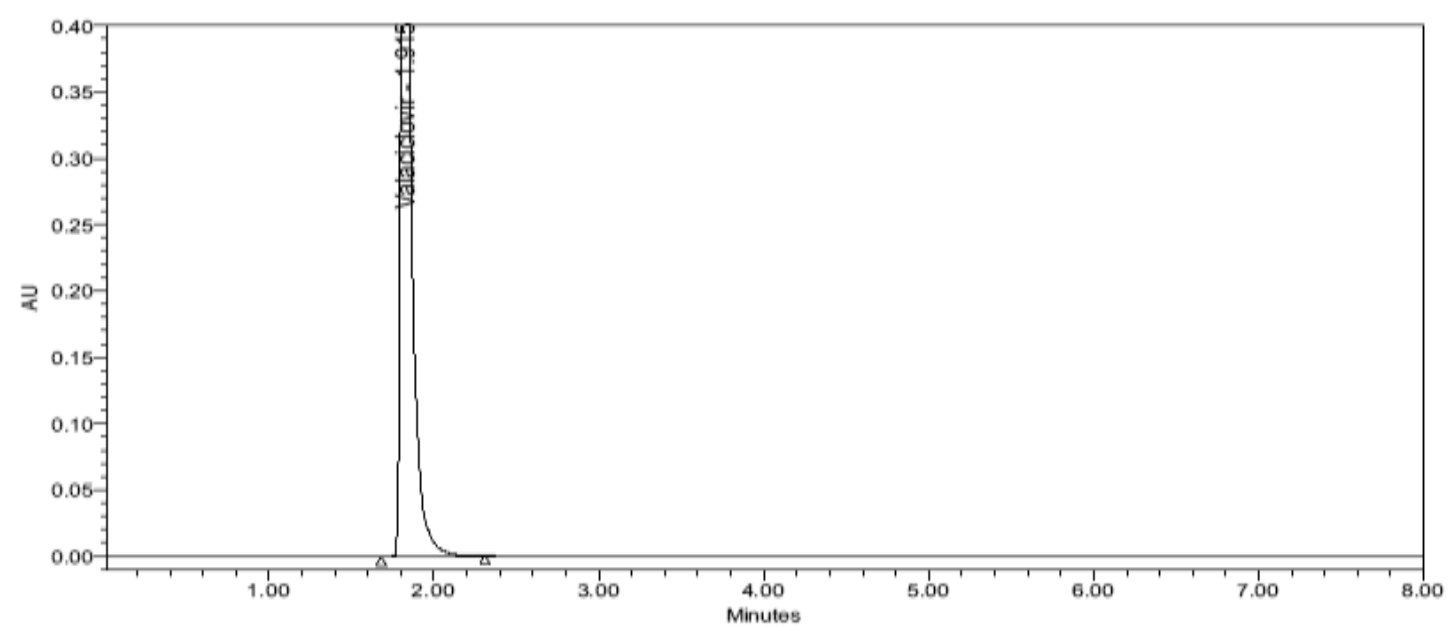

Fig: 39.Chromatogram of Robustness (temperature $30^{\circ} \mathrm{C}$ )

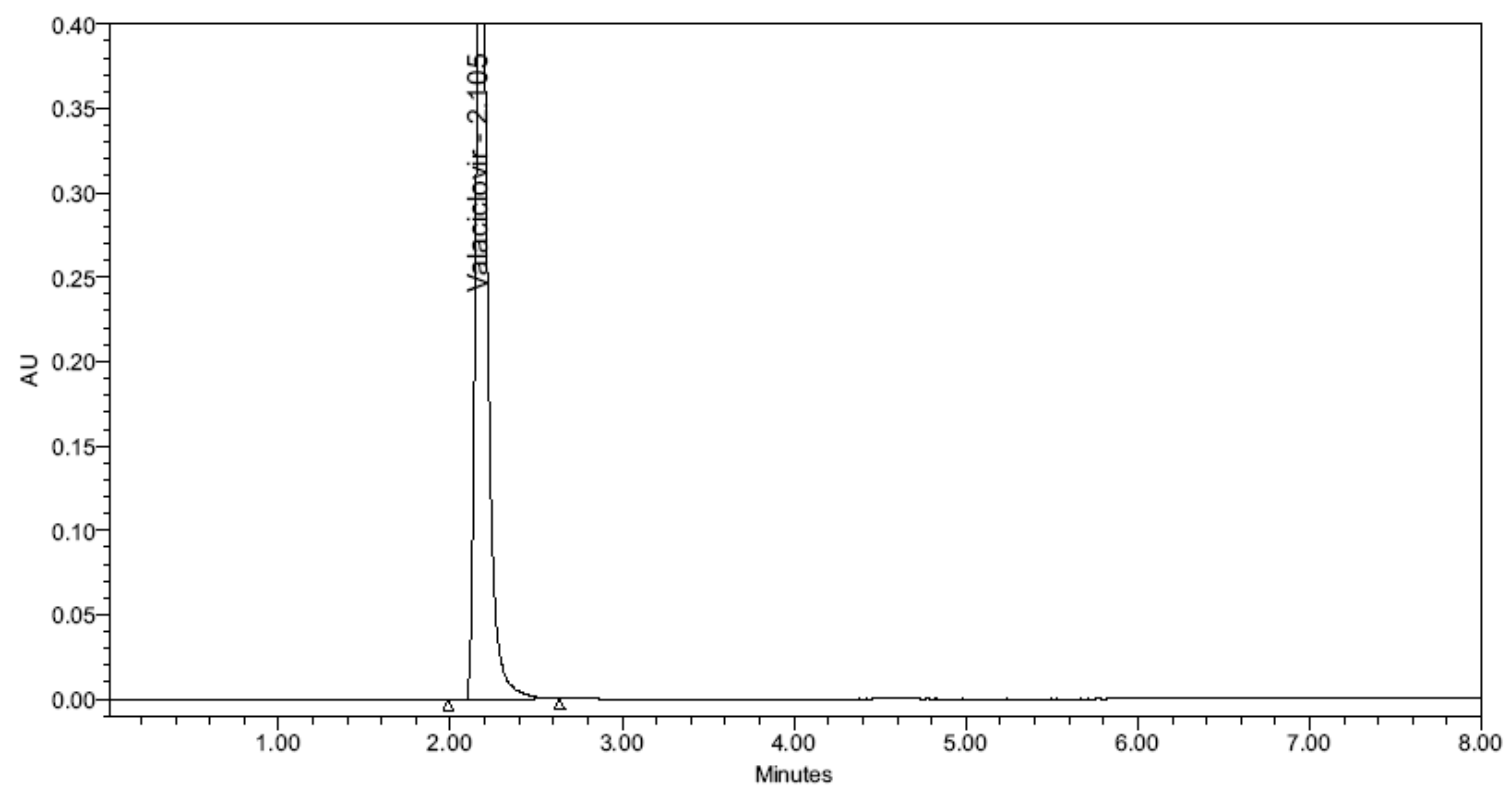

Fig: 40 .Chromatogram of Robustness (temperature $20^{\circ} \mathrm{C}$ )

Table: 11. Robustness Temperature results for Val acyclovir

\begin{tabular}{|c|c|c|c|}
\hline Temperature & Retention Time & Tailing Factor & USP Plate Count \\
\hline 20 & 2.105 & 1.3 & 4827 \\
\hline 30 & 1.915 & 1.3 & 4435 \\
\hline
\end{tabular}

Keeping the ratio of mobile phase constant and the chromatograms of drug solution were recorded with different flow rates such as $0.8 \mathrm{ml} / \mathrm{min}, 1.0 \mathrm{ml} / \mathrm{min}$ and $1.2 \mathrm{ml} / \mathrm{min}$. At the flow rate of $1.0 \mathrm{ml} / \mathrm{min}$, the 
peaks were sharp with good resolution and found to be satisfactory. So $1.0 \mathrm{ml} / \mathrm{min}$ flow rate was kept constant throughout the analysis. The results are presented in Table 10. Keeping the flow rate constant $(1 \mathrm{ml} / \mathrm{min})$ and the chromatograms of drug solution were recorded by changing temperature ,the peaks were sharp with good resolution and found to be satisfactory. The results are presented in Table 11.

\section{CONCLUSION} viral agent.

Valacyclovir is the drug used in the treatment of herpes simplex \& herpes zoster virus . It is an anti-

From literature review and solubility analysis initial chromatographic conditions were set and different trials were run to valacyclovir get eluted with good peak symmetric properties. Mobile phase buffer: water:methanol(50:50), agilent C8 Zorbax column, flow rate $1 \mathrm{ml} / \mathrm{min}$ detection wave length $253 \mathrm{~nm}$, column temperature $25^{\circ} \mathrm{C}$ and diluent Mobile phase, conditions were finalized as optimized method. $0.01 \mathrm{M}$ Orthophosphoric acid solution was used as buffer.

System suitability parameters were studied by injecting the standard five times and results were well under the acceptance criteria. Linearity study was carried out between $20 \%$ to $150 \%$ levels concentration range of $20 \mathrm{mcg} / \mathrm{ml}$ to $75 \mathrm{mcg} / \mathrm{ml}$, The regression of valacyclovir was found to be $\mathrm{Y}=873.4 \mathrm{X}+7092.1$, where ' $\mathrm{Y}$ ' is the peak area and ' $\mathrm{X}$ ' is the concentration ofvalacyclovir. The regression equation was used to estimate the amount of valacyclovir, $\mathrm{R}^{2}$ value found 0.9999 .

It can concluded that the proposed methods show good approach for obtaining reliable results which is simple, precise, accurate, sensitive, economic and less time consuming and were found to be suitable for the routine estimation of valacyclovir in bulk and Pharmaceutical dosage forms.

\section{ACKNOWLEDGEMENT}

The completion of this dissertation is not only fulfillment of my dreams, but also the dreams of my Parents, who have taken lots of pain for me in completion of my higher studies.

I take this privilege and pleasure to acknowledge the contributions of many individuals who have been inspirational and supportive throughout my work undertaken and endowed me with the most precious knowledge to see success in my endeavor. My work bears the imprint of all those people, I am grateful to.

Firstly, I offer my adoration to God Almighty who created me, gave me the strength and courage to complete my dissertation.

I am very thankful to Mr. T. Manish kumar assistant professor, department of Pharmaceutical Analysis, Balaji College of pharmacy, Narsampet, Warangal. for his excellent guidance.

I express my sincere thanks to our respected Principal, Dr. T. Tamizh Mani, Bharathi College of Pharmacy, for his co-operation, encouragement and for providing facilities, which enabled me to complete this work successfully.

I express my deep gratitude and special thanks to Dr. K. P. Channabasavaraj, Professor, Head of the Department of Pharmaceutical Analysis, Bharathi College of Pharmacy, for the valuable guidance during the course of study.

\section{Journal Papers:}

\section{REFERENCES}

[1] Stability-indicating liquid chromatographic method for valacyclovir K.Srinivasa Rao*and M. Sunil Roland Institute of Pharmaceutical Sciences, Berhampur-760010, Orissa (India).International Journal of ChemTech Research CODEN (USA): IJCRGG ISSN : 0974-4290 Vol.1, No.3, pp 702-708, July-Sept 2009

[2] A Validated Specific Reverse Phase Liquid Chromatographic Method for the Determination of Valacyclovir in the Presence of its Degradation Products in Bulk Drug and in Tablet Dosage Form G. D. Patil1P. G. Yeole1, Manisha Puranik1 and S. J. Wadher1* Department of Pharmaceutical Chemistry, Institute of Pharmaceutical Education and Research, Borgaon (Meghe), Wardha 442001, Maharashtra, India. International Journal of ChemTech Research ISSN : 0974-4290 Vol.1,No.1,pp 16-26, Jan - March 2009.

[3] UV Spectrophotometric Method for the Estimation of Valacyclovir $\mathrm{HCl}$ in Tablet Dosage Form, E-Journal of Chemistry Volume 6 (2009), Issue 3, Pages 814-818 doi:10.1155/2009/546187

\section{Books:}

[4] ICH: Q2B, Analytical Validation - Methodology (November 1996).

[5] ICH: Q2A, Text on validation of analytical procedure (October 1994).

[6] ICH Q2 (R1), Validation of Analytical Procedures Text and Methodology November 2005. 